\title{
EXPERIMENTAL STUDIES ON VIRAL ETIOLOGY OF EPSTEIN- BARR (EBV) \\ IN NASOPHARYNGEAL CARCINOMA (NPC): ESTABLISHMENT OF EBV INFECTION ON HUMAN EPITHELIAL CELLS DERIVED FROM NASOPHARYNGEAL TISSUES
}

TORU TAKIMOTO, M. D.

Department of Oto-Rhino-Laryngology, School of Medicine, Kanazawa University, Kanazawa

(Director: R. Umeda, M. D.)

and

Department of Virology, Cancer Research Institute, Kanazazwa University, Kanazawa

(Director: M. Hatano, M. D.)

There have been many suggestive evidences on the close correlation between EBV infection and the development of NPC, though the mode of this lymphotropic EBV infection how to enter into the epithelial cells of the nasopharynx and transform the cells to NPC are still unknown. In order to clarify an etiological role of EBV in NPC, several approaches in vitro were tried in this respect, and the results are as follows:

1) EBNA (EBV-associated nuclear antigen) as an expression of EBV infection was found in $5-90 \%$ cells of $4 / 8$ NPC biopsy specimens.

2) Nine tissues of $12 \mathrm{NPC}$ were successfully cultured in vitro. EBNA-positive cells were observed in $2 / 3$ epithelial cells cultured. In fibroblast-like cells from one case, floating cells were appeared and they were isolated without EBV infection for the establishment of the cell line (TNPCly-1). This TNPCly-1 cells clearly showed B lymphocyte markers and EBNA in more than $90 \%$ of the cells.

3) EBNA-negative lymphocytes from cord blood, adult peripheral blood and tonsil were possible to transform in vitro by EBV (B95-8 strain) infection. The transformed cells acquired EBNA and showed also B lymphocyte markers (CBL-E-1, 2, 3, 4, 5; APL-E-1, 2, 3, 4, 5; TON-E-1, 2).

4) Most of the human monolayer cells employed in this experiment (2-27-Ad, T-Ad,Hep-2, $\mathrm{FL}$, Intestine-407, HHEL and AHEL) were not transformed to EBNA-positive by EBV infection. However, 3 floating cells (A $1 \mathrm{~L}, \mathrm{~A} 2 \mathrm{~L}, \mathrm{~A} 3 \mathrm{~L}$ cells) appeared in 6 nasopharyngeal fibroblast-like cells about one month after EBV inoculation. These 3 established cell lines also showed EBNA in more than $90 \%$ of the cells and B lymphocyte markers.

5) In the nasopharyngeal epithelial cells (2-27-Ad cells) which fused with EBNA-negative lymphocytes by UVed HVJ (Sendai virus) and then infected with EBV, EBNA was observed only in the nucleus of polykaryons. On the second day after EBV infection, both lymphocytes and 2-27-Ad cells of polykaryons showed positive staining of EBNA, which suggested an EBV infection in the epithelial cells. Moreover, the induction of both early nuclear antigen (ENA) and early antigen (EA) were possible by $\operatorname{ludR}(70 \mu \mathrm{g} / \mathrm{m} l)$ treatment of the fused cells infected with EBV.

6) Using 2-27-Ad cells, the mutant cells (Ad-AH) defective of emzyme, HGPRT (hypoxanthineguanine-phosphoribosyl transferase), were selected after the treatment of the cells with 8- 
azahypoxanthine. Ad-AH celle were fused with EBNA- and HGPRT-positive A 2 L cells by UVed HVJ and then cultured with HAT (hypoxanthine-aminopterin-thymidine) medium. These somatic cell hybrids (Ad-AH/A 2L) have been maintained for about 6 months with positive EBNA in more than $80 \%$ of the cells in this experiment, and this is a good model for study of NPC in vitro.

$\overline{\mathrm{A} 82-0119-51390}$

\title{
EBV in vitro 感染による上咽頭癌発生機序の実験的研究
}

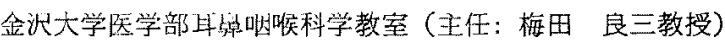 \\ 滰元徹
}

\section{I. 緒㝘}

上咽頭癌と Epstein-Barr virus (EBV) との䦎連性K ついては，1966年 Old $5^{1)}$ の最初の報告に踹を発し，ま ず EBV 関連抗体が，上咽頭癌患者任特翼的に高頻度

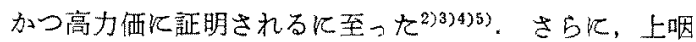

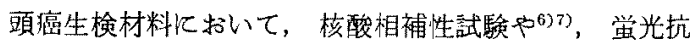
体補体法 ${ }^{8) 9) ~(A n t i-C o m p l e m e n t ~ I m m u n o f l u o r e s c e n c e ; ~}$ ACIF)により，霾䞍周围に浸潤したりンパ球ではなく，

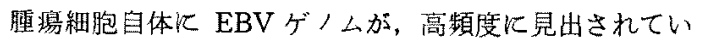

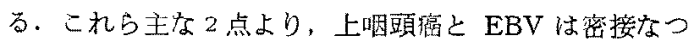
ながりを有していると現在は考えざるを得ないと思わ机 学.

しかし， EBV の感染標的細胞は，ヒトとサルのりン

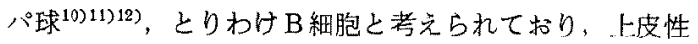
稩胞への直接的感染成立は証明されていない，リン八睎 好性の EBV が上皮性腫惕である上咽頭福ととのような 関係を有し，さらに，いかなる機序にて，上咽頭上皮性 細胞八の感染成立が生ずるかは，興味ある閒題である。

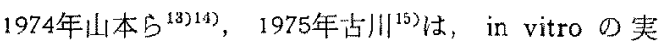
歇にて，EBVゲノム保有細胞（リンパ芽球様細胞）之 上皮性細胞と口細胞融合汇より，融合細胞の上皮性細胞 核内K EBV-associated nuclear antigen (EBNA) 流 発現することを報告した。

そこで，著者岋これらの報告をるらに発展さすべく， 上咽頭上皮性細胞への新たなる EBV 感染成边機作を in vitro 実験で解析しつつ，上咽頭癌発生僟序Kつき考祭 したのでここに報告する。

\section{II. 方法および材料}

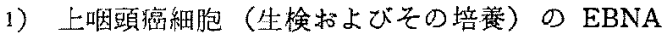
検索

(1) 対舆

金沢大学，石川県立中央病院ならびに富山県立中央病 院耳鼻咽喉科にて，上咽頭癌と㟝断された患者10名によ る上咽頭生検材料扎よび頝部りンパ節摘出組緎12例を対 象とした。ちなみに対照として，上咽頭肉腫 3 例，上咽 頭線維䏸 1 例, 喉頭滰 5 例, 上顎癌 5 例, 計 14 例の組織 を選んだ。

(2) 標本作製法

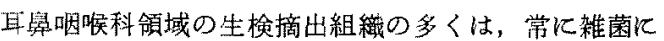
よる污染の可能性があるので，組織の表面は消毒用イン ジン液(明治製)で充分消毒した。ささに多曾の抗生物質 (カナマイシン $5 \mu \mathrm{g} / \mathrm{m} l$, リラシリン $5 \mu \mathrm{g} / \mathrm{m} l$ ) 加 Hanks

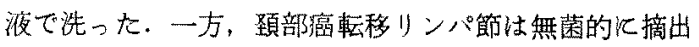
されているため，一回 Hanks 液で洗ってから，周囲脂 肪組織甲被膜を制離, 除去し, 臛瘄組織と思われる部位 を使用した。

これら組織を減菌シャーレの Hanks 液中にて，八サ

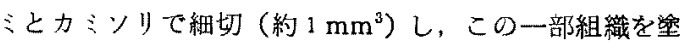
抹潔本に使用した. 牫りの組織は，力バーグラス（10x

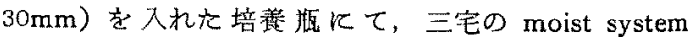

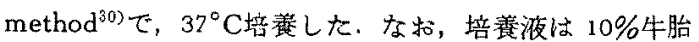
見血清 $\left(56^{\circ} \mathrm{C} 30\right.$ 分韭働化) 加 Eagle's MEM (二ッス 1製）（EF-10）を使用した。

(3) EBNA の検索 (ACIF)

Reedman and Klein $5^{16)}$ の方法の鈴木, 日沼变法 ${ }^{17}$ 


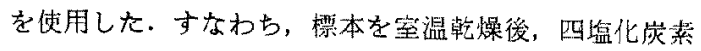
$\left(\mathrm{CCl}_{4}\right)$ で空温 15分固定した.この標本を健邽成人血清 (抗 viral capsid antigen; VCA 抗体傮 1: 160, 抗

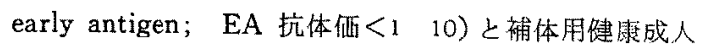
血清（抗 VCA 抗体洒 $<1 \quad 10$, 抗 EA 抗体価 $<1 \cdot 10$ ) とを混合し，それぞれの最䅂婊度 1：10 なるように BSS (balance salt solution) 飞て希积し, 一次血清亡し て使用した，かかる血清にて， $37^{\circ} \mathrm{C} 30$ 分反心後BSSK て洗浄して, 抗ヒト補体蛍光抗体 (FITC- labelled antihuman $\beta_{1} \mathrm{C} / \beta_{1} \mathrm{~A}$, Hyland Lab. U.S.A.) て, さbk $37^{\circ} \mathrm{C} 30$ 分反店させた. そして，再び BSS で洗浄後, 営光顕徽鏡にて観察した。

2）上卜各種培養細胞への EBV 亘接感染実験

(1) 使用細胞

i) ヒト各種リンパ球

A）胎带血ならびに健捸成人末梢血由来リンパ球.

ヘパリンを注射筒に浸し採血後 Conray-Ficoll法 ${ }^{18)} \mathrm{K}$ 従以，リンパ球の分離を行った。年の後，この細胞を Hanks液江て，3回遠心洗浄後，20\%牛胎児血清加RPMI

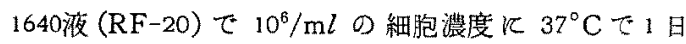
培盖後, 浮遊した単核細胞を使用した。

B）口蓋扇桃リンバ球

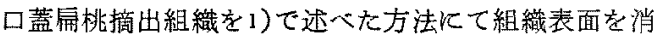
毒後，遠心管 $(40 \mathrm{~m} l$ 用) K入れ，下甲介揱刀にて細切し た. そして，Hanks液を加えた後，ガーゼと金属メッシ ュを通過した浮旅細胞液を Conray-Ficoll 法にて，リン 八球を分離した，以下，A）の方法之同様にて培罴後， 使用した。

ii) 七上上咽頭由来單層培㙋細胞

A）上皮性細胞

a) 2-27-Ad 細胞 ${ }^{15)}$

b) T-Ad 細胞：著者は，1)の上咽頭癌生検村料による 初代培養法と同様に，アデノイド組織の培袁を行った。

その結果，2-27-Ad 細胞と洞様に樹立化に成功した細 胞株.

いずれも10\%仔牛血清加 Eagle's MEM (EC-10)で $37^{\circ} \mathrm{C}$ に培養された。

\section{B）線維芽様細胞}

$\mathrm{AdF}_{1} \sim \mathrm{AdF}_{6}$ 細胞： ii) A) b) と同様の初代培䍜を行 い，1回継代を行って得られた細胞で，培羕液には EF10を用い， $37^{\circ} \mathrm{C}$ で培蘶した。

iii）その他七ト各種単啳培善細胞

A) 線維芽槏細胞

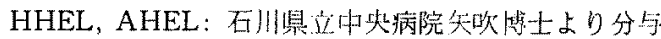
を5けた胎巟麻由来維胞で継代数10代以内の diploid 縕

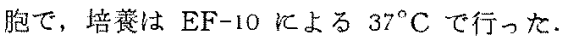

B）上皮性細胞株

Hep-2 (㬋頭癌由来), Intestine-407 (胎先小渴由来), FL (羊膜由来)：いずれも EC-10 で $37^{\circ} \mathrm{C}$ 培息した。

(2) $\mathrm{EBV}$ 液

B 95-8細胞 ${ }^{10)} 3 \times 10^{5} / \mathrm{ml}$ の緗胞涉度て RF-10K浮

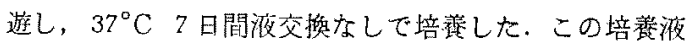

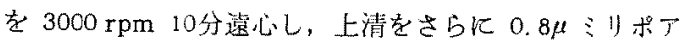
フィルターにて沪過した液を使用した。

なお，感染ウィルスの定量は，50\% of transforming dosis $\left(\mathrm{TD}_{30}\right) / \mathrm{m} l$ kて算出した ${ }^{192}$. 寸なわち EBV 夜 の10倍段階希积液を七ト腹带血由来りンパ球に接種し， 約 1 力月観察してリンパ球のトランスフォーメーション （液の酸性化，芽球化細胞のクランブ死成，EBNA陽性） した最終希彩漂度を Reed and Muench 法で算出した。 なお，著者の使用した EBV液は $10^{4} \mathrm{TD}_{50} / \mathrm{ml}$ である。

(3) $\mathrm{EBV}$ 接種法

i) リン八球への感染

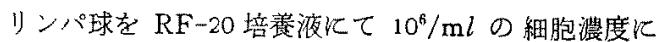
浮避さ世, その $0.8 \mathrm{~m} l$ k0. $2 \mathrm{~m} l$ の EBV 液を加え，全量

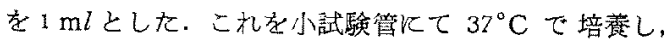
その後週 2 回の液交換老行ない,りンパ球のトランスフ オーメーションを観察した.

ii）単層培養細胞入の感染

培羡液を吸引後, $\mathrm{EBV}$ 液を細胞面が浸る程度に入れ, $37^{\circ} \mathrm{C} 90$ 分吸着さ吠た. Hanks 液で 1 回洗った後, EF10 加光 $37^{\circ} \mathrm{C}$ 亿培盖した. EBV 感染成立の証明は, 感染後連日 1 週間, 2 週間後, そして約 $1 \sim 2$ 力月後の EBNA 観祭にて行った。

(4)各種りンパ芽球様細胞秝の免没学的同定

i）ロゼット形成反応

これら 3 種類の 反応は，失田ら ${ }^{202}$ 扰よび Robinson ら

ii）細胞買内免疫グロブリンの湌出

室温10分アセトン固定細胞を抗七ト（IgG，IgM，また は IgA）蛍光色菜ラベル血清にて $37^{\circ} \mathrm{C} 1$ 時間反応させ て，䑰光影微鏡で観祭した。

3) EBNA 险性七トリンパ球との融合（新方法）飞 よる 2-27-Ad 細胞への EBV 感染䒠験。

(1) 使用細胞

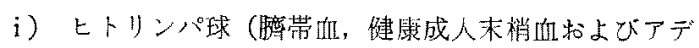


（1ド由来）：2）i）A）B）の方法飞分晟し，EBNA 陰 性を確瑟してあるりン八゚球 ii) 2-27-Ad 細胞: 前記と 同じすのである。

(2) 使用於ルス

HVJ (Hemagglutinating Virus of Japan または Sendai Virus)：名古屋-1-60株接種発育楾卵（10日卵） より集的た等尿液の $7,000 \times \mathrm{g}$ で20分遠心上清をさらに $25,000 \mathrm{rpm}$ て 60 分超遠心し, 法渣を PBS (Phosphate buffered saline) 飞浮遊娞, 超音波処理に上り均 一化した半精製 HVJ を使用した。なお，使用にあた っては,この HVJ 液老 Hanks 液で希釈 (8000HAU/ $\mathrm{m} l)$ 後, 紫外線ランプ (UV) $(100 \mathrm{erg} / \mathrm{sec} / \mathrm{mm}) 飞 て$, 10分照射し，不活化して使用した。

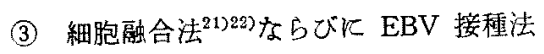

2-27-Ad 細胞を通常のトリブシナイゼーション法に て単離させ，Hanks 液て $4 \times 10^{6} / \mathrm{ml}$ の細胞濃度飞浮遊 した.またリンバ球む $2 \times 10^{7} / \mathrm{ml}$ の細胞濃度にて Hanks 液に浮遊させた. 加かる 2 種頑の細胞を $0.25 \mathrm{~m} l$ ずつ (すなわち $1: 5$ の割合に) 混合させ,さらK IHVJ 液 $(8000 \mathrm{HAU} / \mathrm{m} l) \quad 0.5 \mathrm{~m} l$ を加え, 全量を $1 \mathrm{~m} l$ Kした. その後, $4^{\circ} \mathrm{C} 10$ 分の反応浽より細胞㠜集を执こさせ，コ

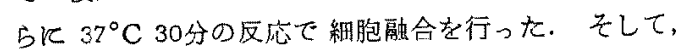

Hanks 液で 3 回遠心洗浄後, (1) ただちに EBV 液 $5 \mathrm{ml}$ とて細胞を浮遊し， $37^{\circ} \mathrm{C} 90$ 分 $\mathrm{EBV}$ を吸着させ，一方 (2) 細狍融合後 $\mathrm{EF}-10 \mathrm{~K} \tau 37^{\circ} \mathrm{C} 24$ 時間培盖後, 培葲 液を吸引儿, $\mathrm{EBV}$ 液 $37^{\circ} \mathrm{C} 90$ 分吸着させた. その後, (1)(2)ずれの場合む接種末吸着 EBVをすて，Hanks液 で1 回洗浄後, 新しい培美液 $(\mathrm{EF}-10) k 37^{\circ} \mathrm{C}$ で培 墡した。

(4) early nuclear antigen (ENA $)^{23324)}$, early antigen $(\mathrm{EA})^{25) 26}$ 検出のための営光抗体間接法

上咽頭癌患者血清で，異好性抗核抗体ならび抗細胞 質抗体を認めない血清水上る一次反応後の蛍光抗体間接 法を行った。 二次反応の栄光抗体としては，抗ヒト $\gamma^{-}$ グロプリン监光色美ランル血清を使用した.

4） EBV ゲ/ム保有雑種細胞（単層培養細胞）の選 別.

\section{(1) 使用細胞}

i) Ad-AH: 2-27-Ad 細泡の HGPRT (hypoxanthineguanine-phosphoribosyltransferase) 欠掐株 で, Szybalski $5^{27}$ Kよる Detroit $98 \mathrm{~S} 0$ HGPRT 欠損㧣選 别法江準し，8-azahypoxanthine (8-AH) 耐性株選別を 行ない, 8-AH $(20 \mu \mathrm{g} / \mathrm{ml})$ 加 EC-10 炕て增殖可能と

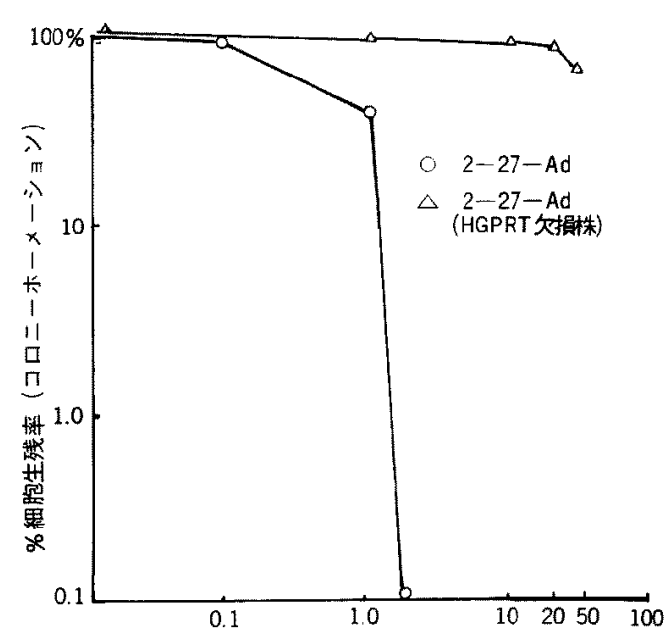

図 1. 8-azahypoxanthine $の$ 常時接触 している条件下でのコロニー形成率 ( $\log \log$ プロット)

なった 8-AH 耐性細胞（図 1).

ii） $\mathrm{A}_{2} \mathrm{~L}$ (ヒトアデ/イド由来 EBNA 陽性リンパ芽様

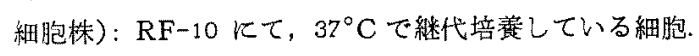
(2) 細胞融合法ならびル培羡法

3)で述べた細胞融合法と同様にして行った. かかる反

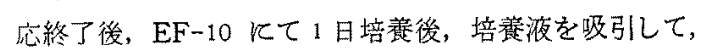
HAT (EF-10+Hypoxanthine $1 \times 10^{-4} \mathrm{M}$ Aminopterin $4 \times 10^{-7} \mathrm{M}$, Thymidine $1.6 \times 10^{-5} \mathrm{M}$, Glycine $3 \times 10^{-6} \mathrm{M}$ )

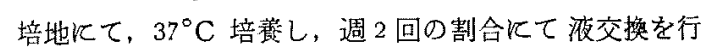
った.

\section{III. 成}

1）上咽頭癌細胞（生検扣よび培養）の EBNA 検索 (表 1)

上咽頭営生検材料仁上る筀抹標本では，8例中 4 例の

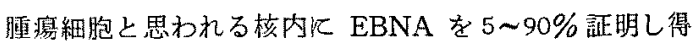
た（写萁 1).またこの生検材料比よる初代培養は，12 例中 9 例分培責飞成功した，そのろち，6例は線維芽様 細胞のみ， 3 例恃上皮性細胞と線維芽梯細胞加湿在して いた.これらの細胞の EBNA を調べたところ，2例の 上皮性細胞が EBNA 陽性であった（写真 2，3）。しか 屯,この EBNA 陽性を示した上皮性細胞は，癌転移り

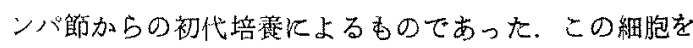
さら継代を重极ると，2代目上り，上皮性細胞住注之 んど瑮められなくなり，線維芽様細胞のみとなった。し 
表 I 上咽頭癌組織の EBNA 検索

\begin{tabular}{|c|c|c|c|c|c|c|c|}
\hline 患者名 & $\begin{array}{l}\text { 性 } \\
\text { 別 }\end{array}$ & $\begin{array}{l}\text { 年 } \\
\text { 齢 }\end{array}$ & $\begin{array}{l}\text { 抗 } \mathrm{EBV} \text { 抗体価 } \\
(\mathrm{VCA}) \quad(\mathrm{EA})\end{array}$ & 病 理 診 断 & $\begin{array}{l}\text { 培鈢材料 } \\
\text { (生検部位) }\end{array}$ & $\begin{array}{l}\text { 塗末標本に } \\
\text { よる EBNA } \\
\text { の証明 }\end{array}$ & $\begin{array}{l}\text { 初代培養細胞の形態ならびに } \\
\text { その細胞の EBNA の証明 }\end{array}$ \\
\hline K. N. & $\hat{o}$ & 66 & $1: 320$ & $\begin{array}{l}\text { transitional } \\
\text { cell ca. }\end{array}$ & Ly. ${ }^{1)}$ & N. D. ${ }^{3)}$ & 増殖せず \\
\hline \multirow{2}{*}{ T. I. } & \multirow{2}{*}{$\delta$} & \multirow{2}{*}{41} & \multirow{2}{*}{$1: 320$} & \multirow{2}{*}{$\begin{array}{l}\text { epidermoid } \\
\text { ca. }\end{array}$} & NP. ${ }^{2)}$ & \multirow{2}{*}{ N. D. } & 雑菌による污染 \\
\hline & & & & & Ly & & $\begin{array}{l}\text { 線維芽様細胞・浮遊細胞 } \\
\text { EBNA }(-) \\
\text { EBNA (+) }\end{array}$ \\
\hline T. S. & $\hat{o}$ & 51 & $1: 320$ & $\begin{array}{l}\text { transitional } \\
\text { ca. }\end{array}$ & NP. & $\begin{array}{l}10-20 \% \\
\operatorname{EBNA}(+)\end{array}$ & $\begin{array}{l}\text { 線維芽様細胞 } \\
\text { EBNA }(-)\end{array}$ \\
\hline K. N. & $\hat{\delta}$ & 68 & $1: 640$ & $\begin{array}{l}\text { invasive } \\
\text { epidermoid } \\
\text { ca. }\end{array}$ & NP. & $(-)$ & $\begin{array}{l}\text { 線維芽様細胞 } \\
\text { EBNA }(-)\end{array}$ \\
\hline $\mathrm{K} . \mathrm{K}$. & Q & 52 & $1: 160<1: 10$ & $\begin{array}{l}\text { invasive. } \\
\text { epidermoid } \\
\text { ca. }\end{array}$ & NP. & $(-)$ & $\begin{array}{l}\text { 線維芽様細胞 } \\
\text { EBNA (一) }\end{array}$ \\
\hline S.M. & 우 & 58 & $1: 2560$ & $\begin{array}{l}\text { undifferential } \\
\text { cell ca. }\end{array}$ & Ly. & $\begin{array}{l}80-90 \% \\
\operatorname{EBNA}(+)\end{array}$ & $\begin{array}{l}\text { 上皮性細胞・線維芽様細胞 } \\
\text { EBNA }(+) \\
\text { EBNA (-) }\end{array}$ \\
\hline K. N. & 우 & 38 & $1: 320$ & $\begin{array}{l}\text { transitional } \\
\text { cell ca. }\end{array}$ & Ly. & $\begin{array}{l}60-70 \% \\
\operatorname{EBNA}(+)\end{array}$ & $\begin{array}{l}\text { 上皮性細胞 - 線維芽様細胞 } \\
\text { EBNA (+) } \\
\text { EBNA (-) }\end{array}$ \\
\hline K. M. & $\delta$ & 64 & $1: 320$ & $\begin{array}{l}\text { epidermoid } \\
\text { ca. }\end{array}$ & NP. & $(-)$ & $\begin{array}{l}\text { 線維芽様細胞 } \\
\text { EBNA }(-)\end{array}$ \\
\hline \multirow{2}{*}{ Y.N. } & \multirow{2}{*}{$\widehat{o}$} & \multirow{2}{*}{47} & \multirow{2}{*}{$1: 320$} & \multirow{2}{*}{$\begin{array}{l}\text { epidermoid } \\
\text { ca. }\end{array}$} & NP. & \multirow{2}{*}{$\begin{array}{c}5-10 \% \\
\operatorname{EBNA}(+) \\
(-)\end{array}$} & $\begin{array}{l}\text { 上皮性細胞 - 楾維芽様細胞 } \\
\text { EBNA (一) } \\
\text { EBNA (-) }\end{array}$ \\
\hline & & & & & Ly. & & 増殖せず \\
\hline S. B. & $\delta$ & 59 & $1: 1280 \quad 1: 640$ & $\begin{array}{l}\text { transitional } \\
\text { cell ca. }\end{array}$ & NP. & N. D. & $\begin{array}{l}\text { 線維芽様細胞 } \\
\text { EBNA }(-)\end{array}$ \\
\hline
\end{tabular}

1) Ly ; 頚部転移リンパ節

2) NP; 上咽頭

3) N. D .; Not Done

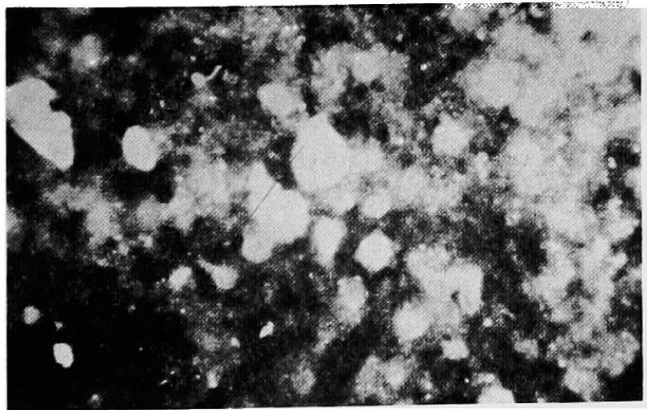

写真 1.上咽頭生検塗抹標本による EBNA の 证明 $\times 400$ (ACIF)

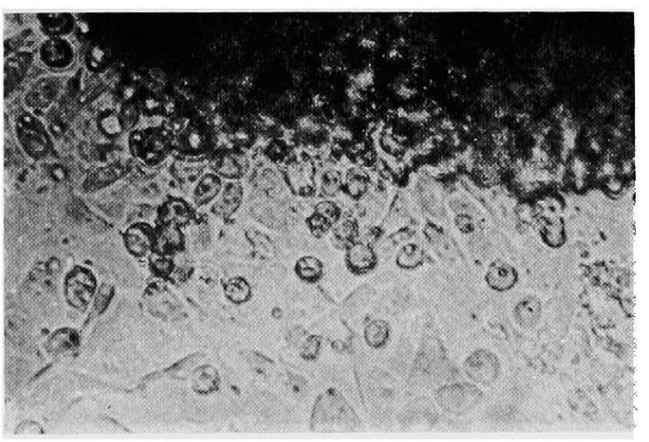

写真 2. 上咽頭癌組織に上る初代培養細胞 （上皮性細胞）培養 1 週目 $\times 200$ 


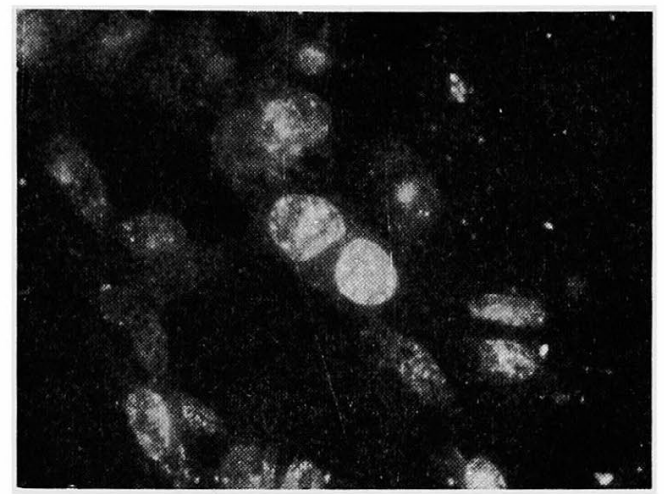

写真 3. 上咽頭癌組織による初代培養細胞 （上皮性細胞）の EBNAの証明. $\times 400$ (ACIF)

かも, これらの線維芽様細胞のうち, 9 例中 8 例が, 3 〜 6 力月 $(20 \sim 30$ 代継代) 後, 細胞の増殖は停止して, 樹立化に成功しなかった. 一方, 残りの1例においては 3 代継代後（初代培養後26日目）より, 線維芽様細胞間 に円形細胞の出現を認めた (写真 4). その後, 急激に 増殖してコロニーを形成し，さらに，コロニーの中心部 より浮遊してクランプをつくるに至った (写真 5 ). こ の浮遊細胞を集め, 継代培養すると, 一部ガラス面には りつきながら増殖し，樹立化に成功した（TNPCly-1）.

この細胞の免疫学的特徽としては, EBNA は 90\%以 上陽性, E-rosettes 陰性, EAC-rosettes $72 \%$ (写真 6) 陽性, 陰性, 細胞質内免疫グロブリン ( IgG 12\%, IgM 62\%（写真 7) IgA 6\%) 陽性であった.このことは， この細胞が $\mathrm{EBV}$ 感染リンパ芽球様細胞であり, 同時飞 B リンパ球としての特徵を有していることを示している (表 IIa).

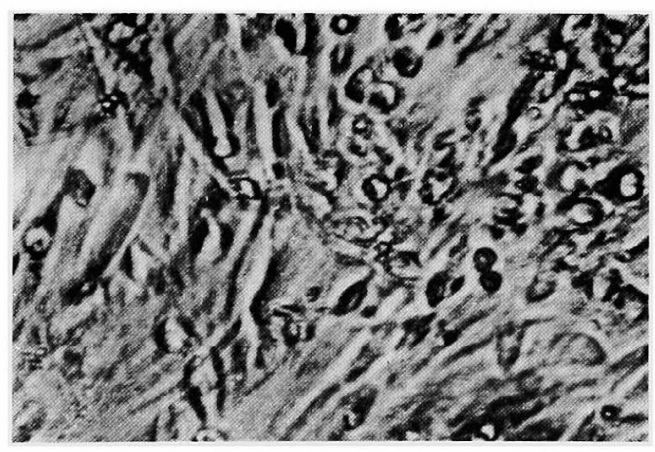

写真 4. 上咽頭癌生検組織培養細胞（線維芽様 細胞）よりの円形細胞の出現像，培香 28 日目 $\times 200$

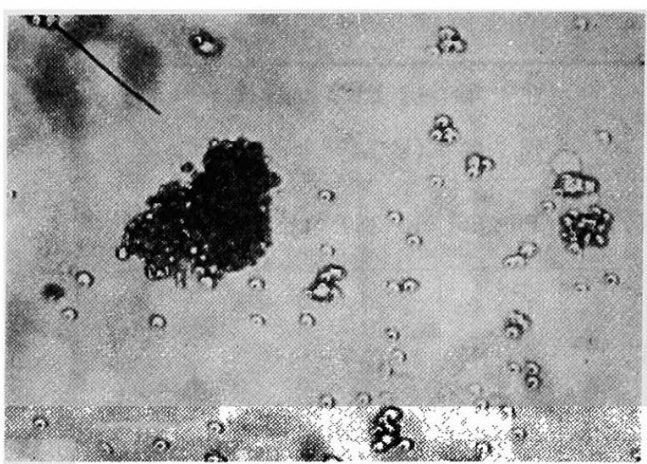

写罜 5. T NPC ly-1 のクランプの形態 $\times 100$

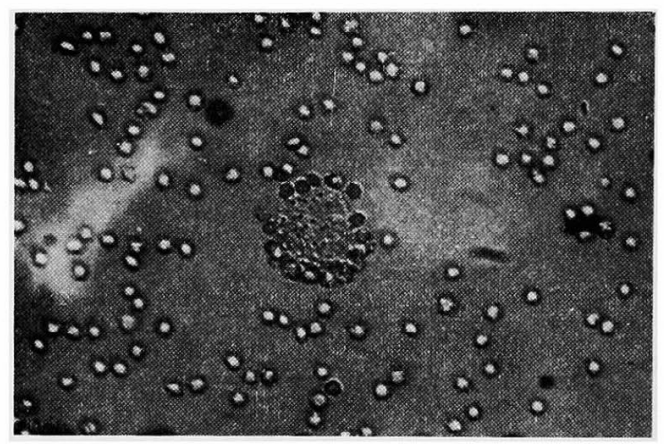

写真 6. T NPC ly-1 の EAC rosette formation $\times 400$

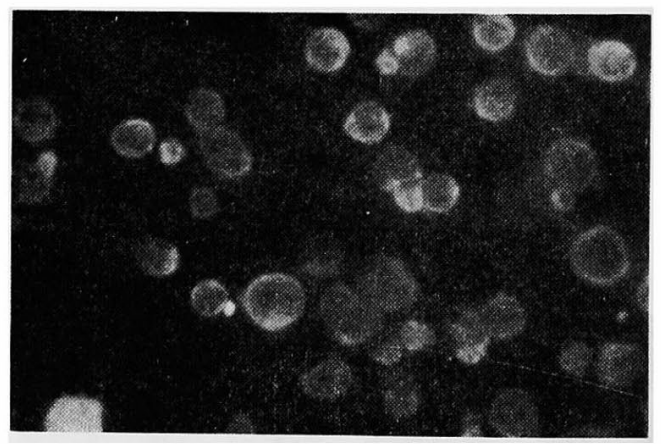

写真 7. T NPC ly-1 の細胞質内免疫グロブリン (IgM) の検出（蛍光写真） $\times 400$

一方, その他上咽頭癌以外頭頝部悪性腫瘍細胞の検索 では，14例中 1例も EBNA を認めなかった. しかも TNPCly-1 のごときリンパ芽球様細胞の出現は 1 例あ 見られなかった。

2）ヒト各種培恶細胞への EBV 直接感染実験

(4) ヒト各種リンパ球（表 IIb） 


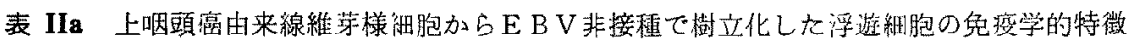

\begin{tabular}{|c|c|c|c|c|c|c|c|c|}
\hline \multirow{3}{*}{ 浮避細胞 } & \multirow{3}{*}{$\begin{array}{l}\text { 初代培養加 } \\
\text { 樹立化するま } \\
\text { での日数 }\end{array}$} & \multicolumn{7}{|c|}{ リンパ球の免疫学的特徵 } \\
\hline & & \multirow[b]{2}{*}{ E B N A } & \multirow[b]{2}{*}{$\mathrm{E}$} & \multirow[b]{2}{*}{ EAC } & \multirow[b]{2}{*}{$\mathrm{EA}(7 \mathrm{~S})$} & 一南 & \multicolumn{2}{|c|}{ 胞質 内 } \\
\hline & & & & & & $\mathrm{IgG}$ & M & A \\
\hline TNPCly-1 & 26(日) & $>90 \%$ & $0 \%$ & $72 \%$ & $\zeta$ & $12 \%$ & $62 \%$ & $6 \%$ \\
\hline
\end{tabular}

表 IIb B 95-8由来E B V 感染飞よりトランスホームしたリンパ等球様細胞株の免度学的特徵

\begin{tabular}{|c|c|c|c|c|c|c|c|c|}
\hline \multirow{2}{*}{$\begin{array}{l}\text { リンパ芽球样 } \\
\text { 細胞株 }\end{array}$} & \multirow{2}{*}{$\begin{array}{l}\text { リン八球是供 } \\
\text { 者の茫 } \mathrm{B} \\
\text { 抗価 } \\
\text { VCA EA }\end{array}$} & \multicolumn{7}{|c|}{ リンパ球の免疫学的特徽 } \\
\hline & & E B N A & $\mathrm{E}$ & $\mathrm{EAC}$ & $\mathrm{EA}(7 \mathrm{~S})$ & $\operatorname{IgG}$ & $\begin{array}{c}\text { 胞 質 } \\
\mathrm{M}\end{array}$ & 为 \\
\hline $\mathrm{CB} \mathrm{L}-\mathrm{E}-1^{12}$ & & $>90(\%)$ & $0 \%$ & $\zeta$ & $\zeta$ & $12(\%)$ & $64(\%)$ & 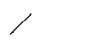 \\
\hline 2 & & $>90$ & 0 & $62(\%)$ & $Y$ & 14 & 52 & $0(\%)$ \\
\hline 3 & & $>90$ & 0 & $\zeta$ & 0 & 15 & 50 & 0 \\
\hline 4 & & $>90$ & 0 & 51 & 0 & 6 & 48 & $r$ \\
\hline 5 & & $>90$ & 0 & 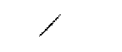 & 0 & 9 & $\zeta$ & 1 \\
\hline A P L $-E-1^{2}$ & $1: 160<1: 10$ & $>90$ & 0 & 71 & 0 & 7 & $\gamma$ & 0 \\
\hline 2 & 1: $80<1: 10$ & $>90$ & 0 & $\zeta$ & 0 & 30 & 49 & 0 \\
\hline 3 & $1: 20<1: 10$ & $>90$ & 0 & 54 & 0 & 5 & 64 & 0 \\
\hline 4 & $1: 40<1: 10$ & $>90$ & 0 & 52 & 0 & 21 & 45 & 0 \\
\hline 5 & $1: 40<1: 10$ & $>90$ & 0 & 78 & 0 & 13 & 62 & 0 \\
\hline $\mathrm{TON}-\mathrm{E}-1^{3}$ & $I: 80<1: 10$ & $>90$ & 0 & 46 & 0 & 36 & 51 & 4 \\
\hline 2 & $1: 40<1: 10$ & $>90$ & 0 & 64 & 0 & 8 & 62 & 5 \\
\hline
\end{tabular}

1) C B L-E：㿥带血由来りンパ芽球様細胞株

2) A P L - E : 煡康成人末梢血由来りンパ芽球様細胞株

3） TON-E：屚桃由来リンパ芽球様細胞株

i）碚带血由来リンバ球

5 例の EBV 感染実験において，いずれも2〜3日目 より，リンパ芽球様細胞がクランプを形成し，さらに培 蕌液の酸性化圶生じたこの細胞を集め，継代を重权て 樹立化飞成功した（CBL-E-1，〜5). ちな子に，このリ ンパ芽球様細胞は，免疫学的特徽として EBNA $90 \%$ 以 上陽性, E-rosettes 陰性, EAC-rosettes $52 \sim 62 \%$ 陽性, EA-rosettes 险性，細胞腯内免疫グロブリン（IgG 6〜 $15 \%, \operatorname{IgM} 48 \sim 64 \%$, IgA 0\%) 陽性で Bリンパ球の特 微を有している.

ii) 揵康成人末梢血由来リンパ球

このリンバ球は，僢帯血由来リンパ球と罢なり，卜ラ ンスフォーメーションに至るまでの日数にをれぞれ固体

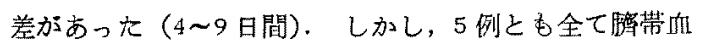
リンパ球と同様樹立化に成功した.

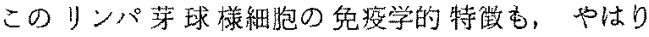
EBNA 90\%以上陽性, E-rosettes 除性, EAC-rosettes 52〜 78\%陽性, EA-rosettes 陰性, 細胞筫内免焙グロブ リン（IgG 5 30\%，IgM 45〜64\%，IgA 0\%）陽性上 リンパ球の特徵有している。

iii）口盐高桃リンパ球

4例の需桃リンパ球のら古，2例がトランスフォーメ 一ションを讃めた。な括このリン八゚第球様紬胞免没学的 特徽もや法り EBNA 90\%以上陽性, E-rosettes 狯性, EAC-rosettes 46 64\%陽性, EA-rosettes $0 \sim 1 \%$ 陽性, 細胞質内免疫グロブリン（IgG 8〜36\%，IgM 51〜62\% IgA 4〜5\%)陽性であった. 特細胞質内免疫グロブリ ン IgA が4〜5\%琶められたことは注目される。

な押これら a) c) の各りンパ球は，EBV 感染前 はいす゚れも EBNA 阥性であった。 
(2) ヒト各種単層培養細胞

i) 2-27-Ad, T-Ad, HHEL, AHEL, Hep-2, Intestine407, FL 各細胞

この 7 種類の各ヒト単層培養細胞への EBV 感染は, 約 2 力月間の経時的 EBNA の観祭にて, 感染成立は証 明し得なかった.

ii) $\mathrm{AdF}_{1} \sim \mathrm{AdF}_{6}$ (アデ/イド由来線維芽様) 細胞 $\mathrm{AdF}_{1} \sim \mathrm{AdF}_{6}$ の初代培養細胞 1 回継代後，培養瓶ぎっ しりに充分堌殖させて, EBV を接種した. その後, 液 交換のみにて継代は行なわなかった. その間 $\mathrm{AdF}_{1}, \mathrm{AdF}_{4}$ $\mathrm{AdF}_{6}$ は感染後それぞれ21日目，32日目，48日目に円形 細胞の出現を認めた (写真 8). その後, 前述の TNPCly1 (上咽頭癌由来線維芽様細胞よりの樹立化浮遊細胞) と 類似の現象がおこり，クランプを形成し，樹立化に成功 した.

$\mathrm{A}_{1} \mathrm{~L}$ は約 1 週間, $\mathrm{A}_{2} \mathrm{~L}$ は約 1 力月間ガラス面に一部 はりつきながら増殖し，その後全ての細胞は浮遊状とな った. 一方, $\mathrm{A}_{3} \mathrm{~L}$ は現在 5 力月間培養するも一部ガラス 面にはりつき增殖し続けている. 加かる $\mathrm{A}_{3} \mathrm{~L}$ 細胞のう ち，ガラス面にはりついた細胞 $\left(\mathrm{A}_{3} \mathrm{M}\right.$ 細胞) ${ }^{60} \mathrm{C}_{0}(400$ rad）照射生後 3 日目のハムスターの皮下に $8 \times 10^{6}$ 個の 細胞を移植した. その結果, 移植後 1 週目に腫瘤を一部 のハムスターに認めたが，次第に退縮し，3 週目には完 全飞消失した. また, ${ }^{60} \mathrm{C}_{0}(400 \sim 1200 \mathrm{rad})$ 照射八ムス ター（生後 2 3 3 月）の cheek pouch 飞移植した場合 あ同様の結果であった (写真 9).

なお，このリンパ芽球様細胞ならびにガラス面にはり ついた細胞は， EBNA 90\% 以上陽性（写真 10）， Erosettes 陰性, EAC-rosettes 60 70\%陽性, EA-rosettes $0.9 \sim 3.8 \%$ 陽性，細胞質内免疫グロブリン（IgG 9 26 \%, IgM 50〜60\%, IgA 6〜10\%) とやはり B リンパ球 の特徵を有していた（表 IIc）

3）新方法による 2-27-Ad 細胞への EBV 感染実験 (図 2,3，4)

各種ヒトリンパ球と 2-27-Ad 細胞とを融合させ, EBV 感染させた.

この際，(1) 細胞融合後, ただちに EBV 感染を行う と，頻度の差はあるが，融合細胞内リンパ球の核に EBNA がまず初めに認められた（写真 11）．その後， 融合 細胞内リンパ球と 2-27-Ad 細胞との両方の核に EBNA が認められた（写真 12）. しかし, 融合 細胞中 2-27-Ad 細胞の核の EBNA 出現が, リンパ球の核の EBNA 出現より先行する例はみあたらなかった，また，

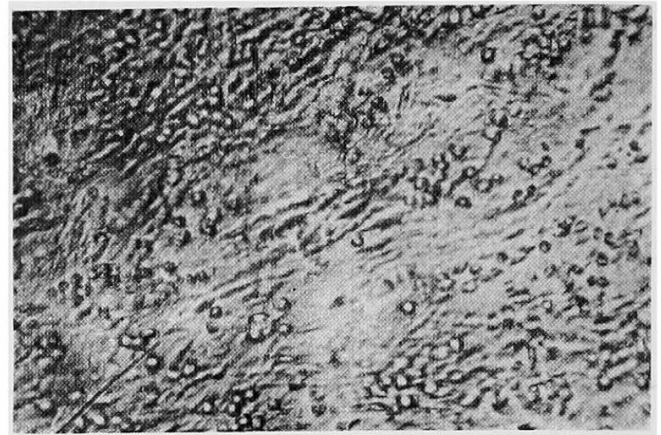

写真 8. アデ/イド由来線維芽様細胞への EBV （B95-8 細胞由来）感染後 50 日目の円形 細胞出現像, $\left(\mathrm{A}_{3} \mathrm{~L}\right)$

$\times 100$

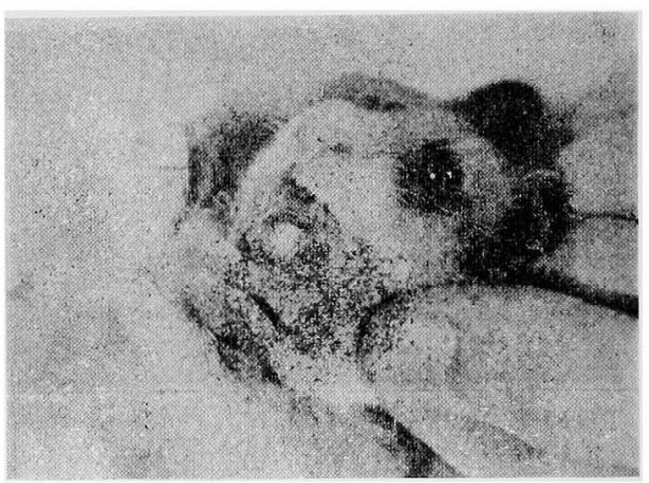

写真 9. 八ムスター (800 $\mathrm{rad}^{60} \mathrm{C}_{0}$ 照射) への $\mathrm{A}_{3} \mathrm{M}$ 細胞 異種移植後 1 週目の cheek pouch 腫瘤出現

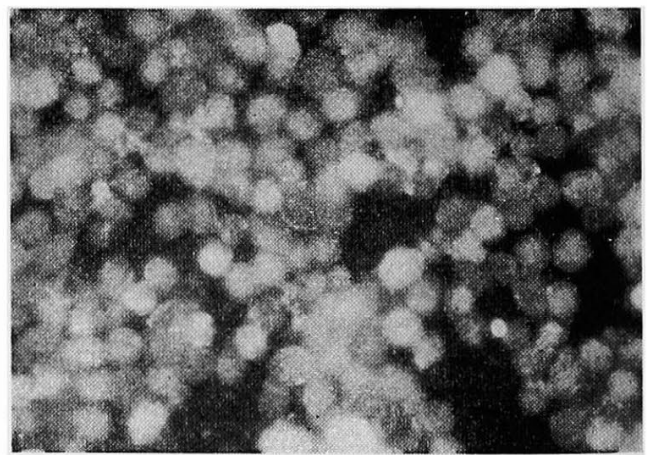

写真 10. $\mathrm{A}_{2} \mathrm{~L}$ 細胞の EBNA 証明 (ACIF)

$$
\times 400
$$

EBNA の経時的観察に肪いて，単層培養細胞の単核紼 胞（扣そらく, リンパ球と 2-27-Ad 細胞の雑種細胞で EBV 感染成立した細胞と思われる.) 飞おいてもEBNA 


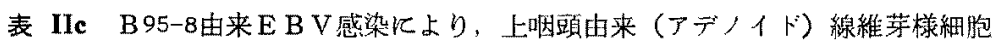
から樯立した浮遊細胞の兔㾤学的特微

\begin{tabular}{|c|c|c|c|c|c|c|c|c|}
\hline \multirow{3}{*}{ 浮遊細 胞 } & \multirow{3}{*}{$\begin{array}{l}\text { E B V 感染後 } \\
\text { 浮遊細胞出現 } \\
\text { までの日数 }\end{array}$} & \multicolumn{7}{|c|}{ リンパ球 $の$ 兔疫学的特徴 } \\
\hline & & \multirow{2}{*}{ E B NA } & \multirow{2}{*}{$\mathrm{E}$} & \multirow[b]{2}{*}{ EAC } & \multirow[b]{2}{*}{$\mathrm{EA}(7 \mathrm{~S})$} & \multicolumn{3}{|c|}{ 細 胞 澌 内 } \\
\hline & & & & & & $\operatorname{Ig} G$ & $\mathrm{M}$ & A \\
\hline $\mathrm{A}_{1} \mathrm{~L}$ & $21(日)$ & $>90 \%$ & $0 \%$ & $70 \%$ & $1.2 \%$ & $14 \%$ & $60 \%$ & $6 \%$ \\
\hline $\mathrm{A}_{2} \mathrm{~L}$ & 32 & $>90$ & 0 & 60 & 0.9 & 26 & 51 & 8 \\
\hline $\mathrm{A}_{3} \mathrm{~L}$ & 48 & $>90$ & 0 & 67 & 3.8 & 9 & 50 & 4 \\
\hline $\mathrm{A}_{3} \mathrm{M} \%$ & $\zeta$ & $>90$ & 0 & 63 & 2.9 & $\gamma$ & $\zeta$ & $\gamma$ \\
\hline
\end{tabular}

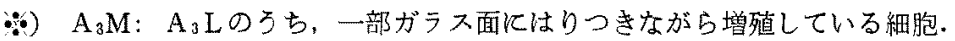
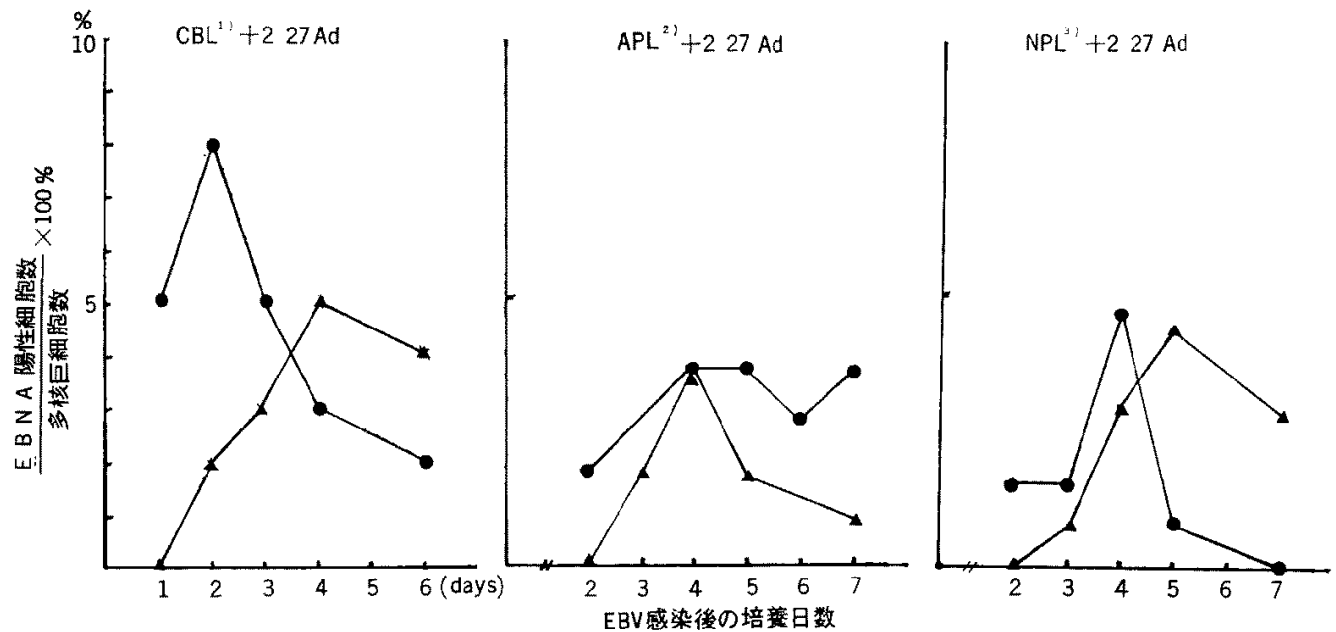

図 2. 各種リンパ球之 2-27-Ad 細胞との細胞础合後, 直ちに EBV (B 95-8 由来) を感染させ，その後の融合細胞内の EBNA 出現頻度の経時的観察。

- 多核巨細胞内のリンパ球核 EBNA のみ陽性

A 多核巨細胞内のリンパ球と 2-27-Ad 两方の核 EBNA 隄性

1) CBL: 娟带血由来リンパ球 2 2) APL：健康成人束梢血由来リンパ球

3) NPL: 上㸶頭 (アデノイド) 由来リンパ球

の出現が認められた（融合細胞中 $0.2 \%$ )(写䡰 13).

その後，約 1 力月の経過観察中, 一部コロニー状に EBNA 陽性の単層培盖細胞（単核細胞）集団を認めた (写真 14).この結果より, EBNA 陽性細胞クローニン グを武みたが，成功しなかった。

次K，(2)リンパ球と 2-27-Ad 細胞との融合後 24 時 間培莔して融合過程をさらに進めた後, EBV を感染さ せた実験に和いても，全く同様に EBNA の核内出現を 融合細胞に認めることができた。

ところでここに用いた各種ヒトリンパ球の細胞融合 前すなわち EBV 感染前はいずれす EBNA 险性です
た、しかし、ここに與味ある1例が認められた。すなわ b，6例のアデ/イド由来りンパ球中1例（抗 VCA 莯 体価 $1 \cdot 160$, 抗 EA 抗体価 <1：10）飞 2-27-Ad 細胞 との細胞融合 2 日後, EBV 非感染で融合細胞内リンパ 球の核に EBNA が証明された（全融合細胞中 $0.25 \%$ ). さらに，この場合は融合 4 日目より。融合細胞内 2-27Ad 細胞の核にも EBNA の出現を認めた（全融細胞中 $0.14 \%)$.

次飞，融合細胞内 EBNA の観祭に加光 ENA, EA検 索の目的飞て，监光抗体間接法を行ったが，これは1例 も認められなかった。しかし，細胞融合に続く EBV 感 


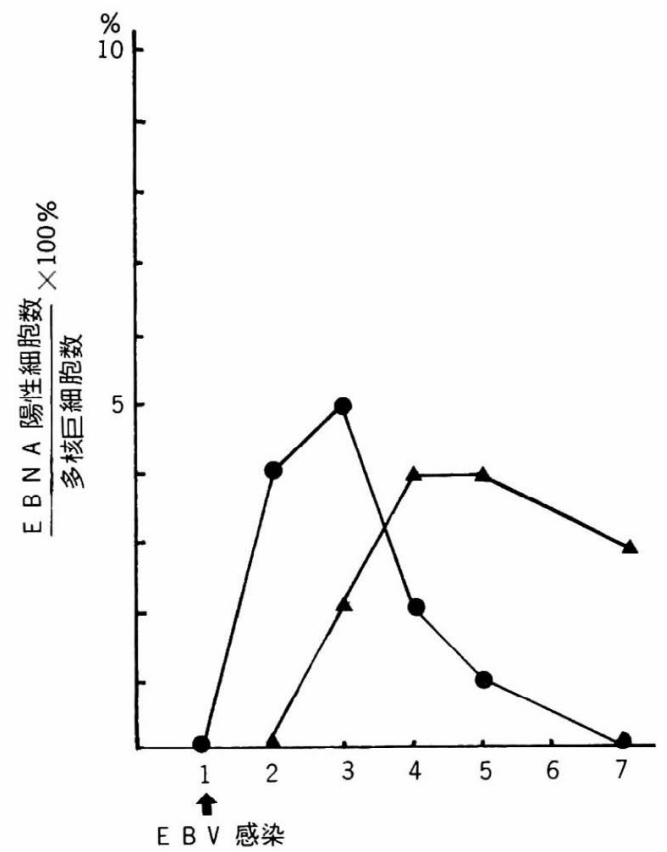

図 3. 細胞融合後の培養日数 胎帯血由来リンパ球と 2-27-Ad 細胞を細胞融合させ $\mathrm{EF}-10$ そて 24 時間 $37^{\circ} \mathrm{C}$ 培養, さらに EBV感染 させその後の融合細胞内の EBNA 出現頻度の経時的観察

多核巨細胞内のリンパ球核 EBNA のみ陽性

A 多核巨細胞内の リンパ球と 2-27Ad 両方核 EBNA 陽性

染 3 日目より 5-Iododeoxyuridine; IudR $(70 \mu \mathrm{g} / \mathrm{m} l)$ 添加による刺激を行うことにより，まず IudR 添加後 1 日目で融合細胞核内に光る蛍光像 (ENA) を認めたが (写真 15), その後この蛍光像は徐々に消失した. 一方, I d R 添加後徐々に, 細胞全体特に細胞質飞蛍光 (EA) の存在する融合細胞の頻度が上昇した（写真 16）.

4) EBV ゲノム保有雑種細胞 (単層培養細胞の選別) $\mathrm{Ad}-\mathrm{AH}$ 細胞と $\mathrm{A}_{2} \mathrm{~L}$ ( $\mathrm{EBV}$ ゲノム保有リンパ芽球様) 細胞とを紫外線不活化 HVJ そより細胞融合させ, HAT 培地飞て培養した. 第 1 週目は液交換を隔日に施行し, その後, 週 2 回の割合にて行なった. その結果, $\mathrm{A}_{2} \mathrm{~L}$ 細 胞と融合しなかった Ad-AH 細胞は, HAT 培地培䞒 後約10日目より細胞の变性を認め, 培梸 3 週目にはほと んど認められなくなった。また， $\mathrm{Ad}-\mathrm{AH}$ 細胞と細胞融 合していない $\mathrm{A}_{2} \mathrm{~L}$ は, 浮遊形態を示し, 頻回の液交換 そて除去できた. かくて $\mathrm{A}_{2} \mathrm{~L}$ 細胞と $\mathrm{Ad}-\mathrm{AH}$ 細胞との

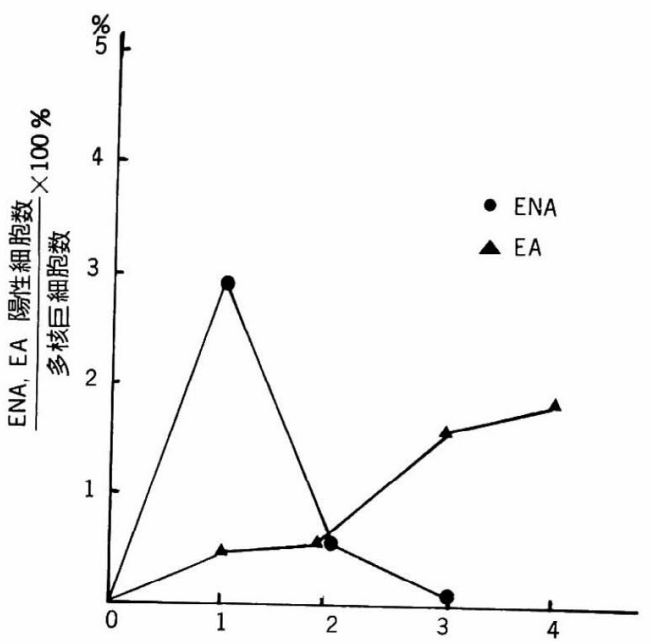

図 4. IudR $(70 \mu \mathrm{g} / \mathrm{m} l)$ 添加後の培盖日数 臍帯血由来リンパ球と 2-27-Ad 細胞 との細胞融合後, 直ちに EBV 感染さ せ EF-10 そて $37^{\circ} \mathrm{C} 3$ 日間 培養して IudR 添加, その後の融合細胞内 ENA と EA の出現頻度の経時的観察.

融合を行ない, HAT 選択培地で培殖可能となった細胞, いわゆる雑種細胞 $\left(\mathrm{A}_{2} \mathrm{~L} / \mathrm{Ad}-\mathrm{AH}\right)$ のみが生存増殖をつ づけ, HAT 培地培羡後約10日目よりコロニーの形成を 認めた. その後, 徐々飞増殖して培養約 1 力月目より継 代可能となった. この雑種細胞は単層培養細胞の形態を し, EBNA は約 80\% 陽性を示した. かかる細胞は現在 に至るまで約 6 力月間にわたり, 増殖しつつ, EBNA 陽性を示し続けている（写真 17）

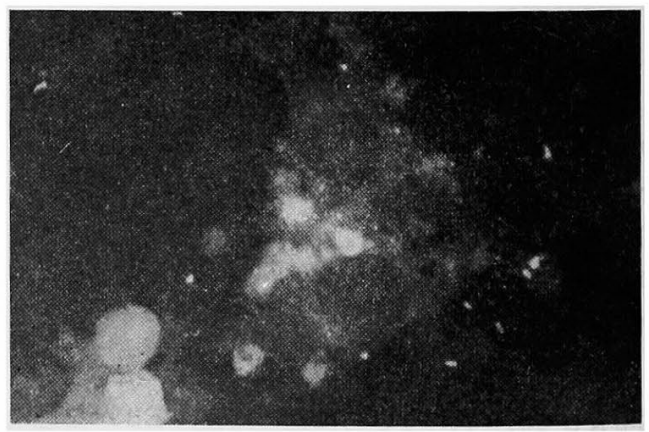

写真 11. 瑏帯血由来リンパ球と 2-27-Ad 細胞 をUV 不活化 HVJ により細胞融合さ せ, EBV 感染後 1 日目に扣ける融合細 胞内リンパ球の核飞 EBNA 出現(ACIF)

$\times 400$ 


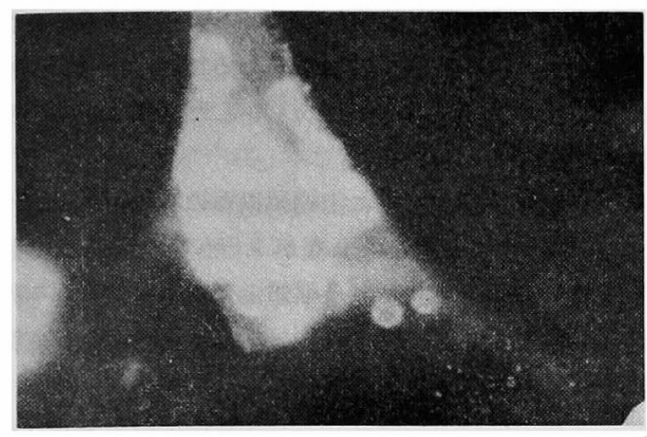

写真 12. 臍带血由来リンパ球と 2-27-Ad 細胞 を UV 不活化 HVJ とより 細胞融合さ せ, EBV 感染後 4 日目における融合細 胞内すべての核に EBNA 出現 (ACIF)

$\times 400$

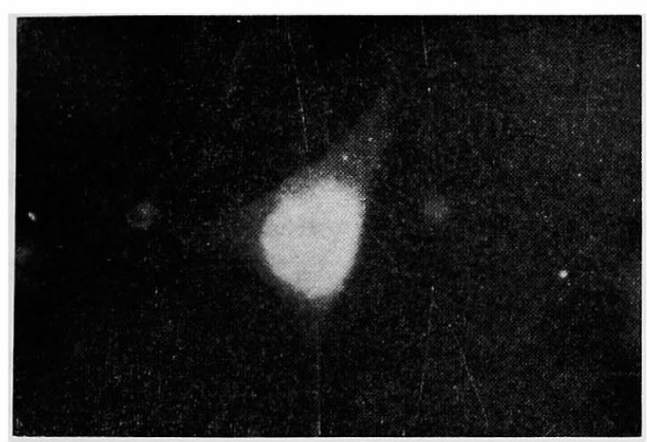

写真 13. 鹁帯血 リンパ球と 2-27-Ad 細胞を UV 不活化 HVJ そより細胞融合させ, $\mathrm{EBV}$ 感染後 5 日目における 単核単層培 教細泡の EBNA 出現 $($ ACIF $) \times 400$

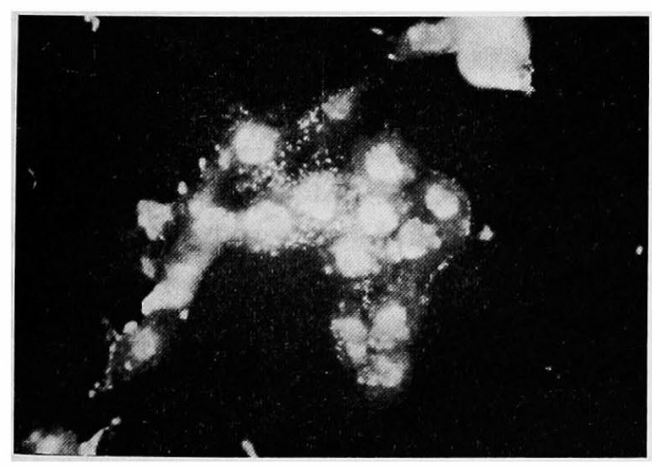

写真 14. 臍带血リンパ球と 2-27-Ad 細胞を UV 不活化 HVJ Kより細胞融合させ, $\mathrm{EBV}$ 感染後, 約 1 力月後, EBNA 陽性 核をもつ单核単層培表細胞コロニー (ACIF) $\times 200$

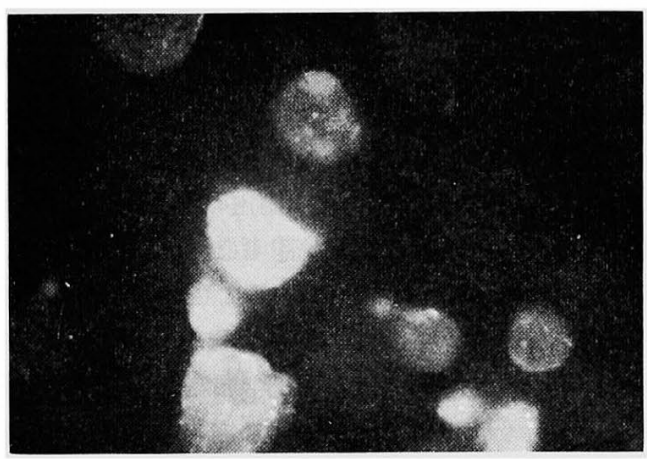

写真 15. 䐉帯血リンパ球と $2-27-\mathrm{Ad}$ 細胞を UV 不活化 HVJ により細胞融合させ, EBV 感染 3 日目に IudR $(70 \mu \mathrm{g} / \mathrm{m} l)$ 添 加後 1 日目の $\mathrm{ENA}$ の蛍光写真 $\times 400$

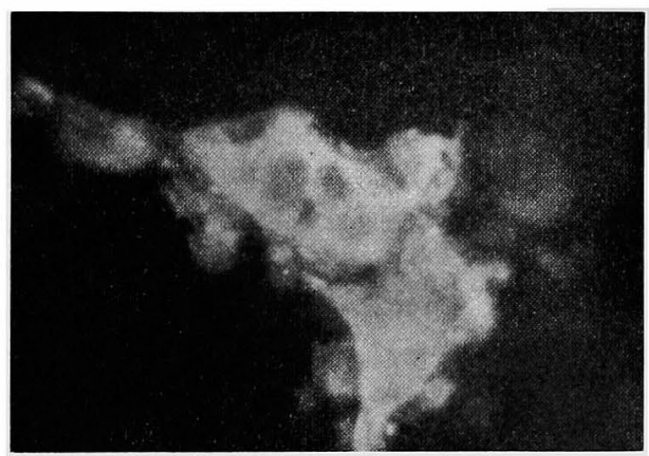

写真 16. 臍帯血リンパ球と 2-27-Ad 細胞を UV 不活化 HVJ Kより細胞融合させ, EBV 感染後 3 日目飞 IudR 添加後 4 日 目の EA の蛍光写真 $\times 400$

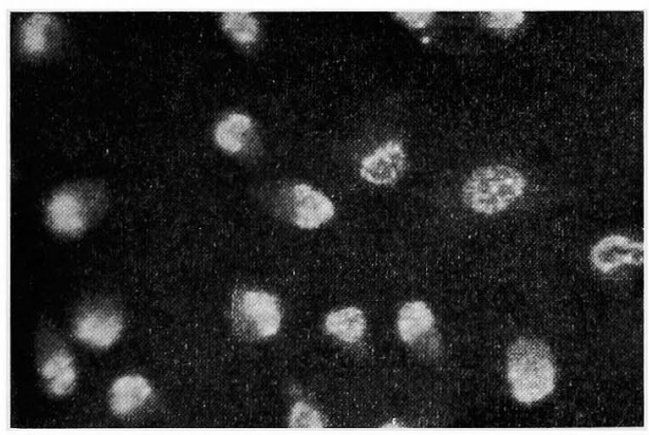

写真 17. $\mathrm{A}_{2} \mathrm{~L}$ 細胞と 2-27-Ad (HGPRT欠損 株）との雑種細胞で HAT 培地にで 6 力 月間維持細胞の EBNA. (ACIF) $\times 200$ 


\section{IV 考察}

上咽頭癌と EBV の関連性を示唆する根拠として，さ

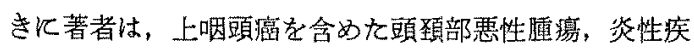

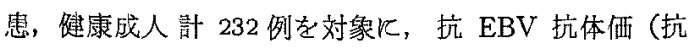
VCA 抗体価之抗 EA 抗体俩) 測定の血清疫学的研究 を行った. その結果, 上咽頭嵒患者血清は, 高類度でし 加も高力佂を特異的飞示した ${ }^{282}$ ，そこで今回，さらに上 咽頭癌ならびそその他頭頝部腫瘍組織に括ける EBNA の存在を検索した. その結果, 上咽頭㰒以外の頭䅡部慙 性腫㾤では 1 例も EBNA を証明できなかっだ，上咽 頭癌では，塗抹標本 8 例中 4 例 (50\%), 上咽頭癌組織 初代培羡細胞とりわけ上皮性細胞 3 例中 2 例 $(67 \%)$ K EBNA 陽性細胞が検出できた。しかも，Southan ${ }^{29)}$ な らびに大星 ${ }^{30)}$ 飞ょれば，リンパ節の粠成細胞中に上皮 性細胞江通常存在しないので, 癌䡉移りンパ節初代培着 K上皮性細胞が出現した時, この細胞は癌細胞と同定し 得るとしている。この見解からすると，著者の EBNA 陽性上皮性細胞 2 例㹥癌細胞之思われる。一方，上咽頭 癌組織の一部症例火は EBNA 陽性細胞を認めながった が.これより一部上咽頭癌では EBVゲ/ムが存在しな いとも考光られろる。しかし，EBNA の出現は細胞增殖

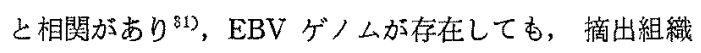
の腫演がすでに唗死飞近い状態であったため， EBNA の発現が不能であった故かむしれない，さらに，上咽頭生 梌の䟢，著者も経験しているが，正しい位置を生検でき ず，正常の上咽頭組織を䛊り採っている可能性もある。 また EBNA のための固定法問題がある場合もあるで あるう、すなわち，細胞固定として著者は $\mathrm{CCl}_{4}$ を使用 したが，この試薬は腫瘍周团の脂肪組織を溶解できず， 㯨癔細胞の固定が不充分上なり，EBNA 検出のできな かったとも考充られる ${ }^{322}$.

以上，述べてきたよろK，1）血清疫学的研究，2）腫 璌細胞内 EBNA の存在上り, 諸家らの報告と同様《上 咽頭癌と EBV は，密接な関連性があることがわかっ た.

そこで，著者はこの $\mathrm{EBV}$ 感染による上咽頭演発生機 序解明のため, in vitroでの各種実騃を行った。

まず P3HR-1 ${ }^{33)}$ 由来感染性 $\mathrm{EBV}$ は，七卜由来算層

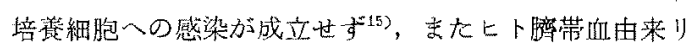
ンバ球一一部感染成立を認めるが，トランスフォーィー

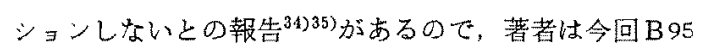
-8 由来感染性 EBV Kよるヒ卜由来各種培羕細胞への 直接感染を行った．その結果，各種りンパ球（驾带血，
健康成人末梢血, 屚桃由来) への EBV 感染成立ならび にトランスフォーメーションを㒛めることができた。ま た，このトランスフォーメーションした細胞は全てBリ ンパ球の特徽を示していた.

一方, 単層培蘶紬胞特飞上咽顽以外の組織由来細胞一 の直接感染成立恬認められなかった。しかし，一部 の前層培垱細胞, とりわけ上咽頭由来線維芽様細跑への $\mathrm{EBV}$ 直接感染で，6例中 3 例 $(50 \%) k$, 円形細胞 の出現さらには浮遊化，クランプの形成がみられた，

これらる種の細胞の非態はリンバ芽球様細胞で Bリンパ 球の特微を有していた。 加かる現象は, 大里 $5^{36)}$, Probert $5^{37)}$ による七卜胎見由米線維第様細胞のトランス フォーメーションと類似する．また，さら飞上咽頭癌由 来線維芽梯細胞加らの浮遊細胞出現をみた高田らの NPC 204 $4^{38389}$ ，著者の今回の TNPCly-1 の出現と屯類 似した現象であった。

ところで，この細胞は，一部の線維芽様細胞には $\mathrm{C}_{3}$

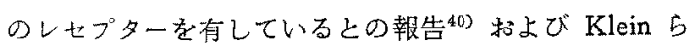
4148)の EBV レセプターとの関連性から考文れば，線 維芽細胞のトランスフォーメーションの可能性するる. しかし、これら細胞 $\left(\mathrm{A}_{1} \mathrm{~L}, \mathrm{~A}_{2} \mathrm{~L}, \mathrm{~A}_{3} \mathrm{~L}\right.$ 細胞) は, B型の リンパ芽球様細胞の特徴を有していた.このことより. 萻者の得た結果は，一部線維芽様細胞間潜儿でいた B リンパ球が EBVの感染をうけ,トランスフォーメーシ ョンした可能性が大きいと考えられた。

ところで， $\mathrm{A}_{3} \mathrm{~L}$ 細胞住現在汇至るも一部ガラス面に はりついて增殖している ( $\mathrm{A}_{3} \mathrm{M}$ 細胞)。そこで, 川村

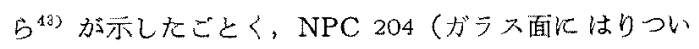
た細胞）のヌ一ドマウス移植による紡錘状細胞癌発生む あるので，著者も， ${ }^{80} \mathrm{C}_{0}$ 照射八人ス夕一人の $\mathrm{A}_{3} \mathrm{M}$ 細胞 移植を試みた。しかし, 移植後 1 週目に腫癌の出現を認 めたが, その後, 徐々飞退縮し, 八ムスターへの巽種移

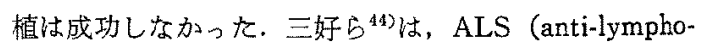
cyte serum) 接種八ムスターへの EBV 感染七卜路帯血 リンパ球哄種移植により, 腫演発生をみているが, 著者 Бの使用した ${ }^{80} \mathrm{C}_{0}$ 照射八よスターは，細胞性免疫の抑 制が不充分のため，成功しなかったすのと考元らる。

以上述べてきたごとく,一部の線維芽様細胞への EBV 宜接感染炕よマランスフォーメーションの可能性も残 っているが，EBV の感染標的細胞恃一般に B リンパ球 とされ，著者毛上皮性細胞一の直接感染成立は完全汇証 明できなかった、しかし、諸家らの竍告ならびに著者の

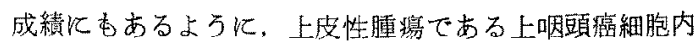


にEBVゲ/んの存在は䛑められているのて，何らかの 機序佀上る上咽頭上皮細胞への EBV 感染は可能な等で ある。このことに関連して，1974年 |1本ら ${ }^{13141}$, 次い で 1975年古川153 は， EBNA 陌性リンバ芽球様細胞之 上皮性細胞との細胞融合により，上皮性細胞の核内《す EBNA が発見することを報告した。ささらた Trumper $ら^{45}$ は, 上咽頭癌生検組織をヌードゥスに異種移植し,

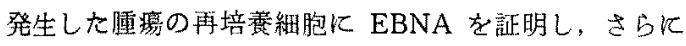
それは人染色体をもったヒ卜細胞であることを確加め た.しかもこの染色体数は tetraploidであったことから みると，リンパ球上上咽頍上皮性細胞との細胞融合のご

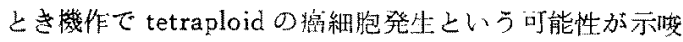
される.しかし，上咽頭癌組織の EBVゲ/ム検索にて，

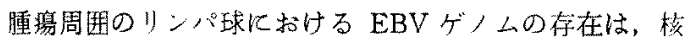
酸相補性試拣中 ACIF 法にて, 检出されていない。 のため,山本ら ${ }^{13)(4)}$, 古川15/の報告による. EBNA 陽性 リンパ芽球様細胞と上皮性細胞との細胞融合を介する上 咽頭癌発生機序仮設によれは，in vivoにおいても細胞 融合していない周迌りンパ球にも EBNA は証明される 筈であるが，上述の in vivoに括ける事奏はこれに反し ている.

そこて，さらに他の機抒による上咽頭上皮性細胞一の $\mathrm{EBV}$ 感染が考えられる.このここに関連して，1972年 Gazzolo 5 ${ }^{46}$ ，1973年 Vuillaume $5^{47)}$ は注目すべき報 告をしている。方なわら，上咽頚由来単層培美細胞閒か らの浮遊細胞（リンパ芽球様細胞）の出現機序解明のた め，上咽頭嵒之上咽頭正常粘膜組織の電子显頁微鏡撮影を 行った. その結果，雨者上屯上咽頭組織に扣けるリンバ 求上上皮性細胞との細胞融合の所見を見出した。この玩 象は，既に癌化している上咽頭嵒細胞核内の EBV ゲノ ムがリンパ球の核内人移行し，その結果リンパ球かトラ ンスフォーメーションするのを示しているのではないか と推論している。しかしながら，これらの報告にはい っさい上咽頭上皮緗肥内几のEBV ゲ/ 人移行機序につ いてはふれていない，そこで著者は上皮性細胞内へ EBV の感染機序として，彼らとは逆の经路を考えた。すなわ b，上咽頭上皮性細胞之正常りンパ球の細胞融合がまず 特こり，この融合細胞が EBVのレセブターを獲得する 上初めて EBV 感染をうけるに至り，ついで上咽䫒上皮 性細胞核内への EBV ゲ/ の癌化が生ずるのではないかという仮説吉て，in vitro での㬰験を行った.そのため，まずヒト各種りンバ球と 上咽頭由来上皮性 2-27-Ad 維胞䒚 UV 不活化 HVJK
て細胞融合後ただちにまたは24脖間培萑後の EBV 感染 上屯，まずリンパ球の核 ついで 2-27-Ad 細胞の核に EBNA 発現が貾められた。この場合，2-27-Ad 細胞の 核に EBNA 発現が，リンパ球の核に EBNA 発現上り

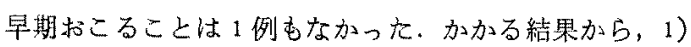
リンパ球核内と 2-27-Ad 細胞核内にも同じ様飞 EBV ゲノムは定着するが，EBNA 発見は，リンパ球の核の 方が早期飞招こりやすい，2）リンパ球の核内にのみ $\mathrm{EBV} ケ ゙$ ， 么定着後 EBNA を合成し，この抗原物筫 (EBNA) のみが 2-27-Ad 細胞の核へ栘行する，3）リ

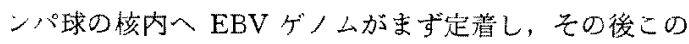
核内で增えたゲ/ムが，2-27-Ad 細胞の核内人移行し， その核で EBNA が発現する. 以上の3つの可能性が EBV ゲ/ $ム の$ 上皮性細胞への定着, 移行, 発現 (EBNA の泟明）僟作減して推諭される.

ところで，この細胞融合実験にて，アデ/イド由来リ ンバ球と 2-27-Ad 細胞との細胞融合のみで $\mathrm{EBV}$ 非感 染例飞括いて一つの與味ある成綪を得た。すなわち6例 のリンパ球の細胞誳合前は，全例 EBNA 陰性であった にもかかわらす，2-27-Ad 細胞との細胞融台に上り，1 例のみ，融合細胞内リンパ球核のEBNA 発現を認めた。 このことは, 融合前の使用リンパ球にも EBNA は存在 していたが，頻度は低く，EBNA の証明がたまたまで きなかったためとも考无られる。しかし，一方では，ご く一部のリンバ球核内に微晊の EBV ゲノムは定着して いるが，核酸性相補性試糇やEBNA 発現微弱のため $\mathrm{ACIF}$ て検出できなかった可能性もある。乙して，加か るリンパ球が 2-27-Ad 細胞との細胞融合とい弓外因性 制激をうけ， EBNA を発現したと考えられる。

この閴題関連して，大里 ${ }^{48)}$ の $\mathrm{PH}-\mathrm{CL}$ 由来感染 性 EBVKよる脳帯血由来りンパ球への感染奏駼はその 可能性を示晙していると思われる。すなわらかかる EBV 感染をうけたリンパ球は，何ら加の刺激をうけない時は EBNA を発現しないが, IudR と Pokeweed mitogen (PWM)に上る刺澈により EBNA 功発現するに至ると いう成續である。この $\mathrm{PH}-\mathrm{CL}$ 由来感染幽 EBV によ り感染をうけたリンバ球は著者の経検したリンバ球に特 ける EBNA 発現と類似のものではないかと考えられ ๖.

以上述べてきた結果をまとめると，EBV 感染による 上咽頭癌発生機序として in vitro 実験で沈次の可能性 が考えられる、1）上咽頭上皮性細胞と EBV ゲ／陰 性リンパ球（B細胞）との融合細胞人 $\mathrm{EBV}$ 感染が生ず 
西が，奏際に柱，初め a）リンパ球の核のみ，ついで b）リンパ球上上皮性細胞の両者の核への EBVゲ/ム 定着比よる EBNA 発現後, EBNA 晹性化雑種細胞（漟 北と考えb扎る）形成，2）EBVゲ/ムを有するが EBNA 発晲のないリンパ球と上皮性細胞の融合粗澈に よるリンパ球の EBNA 発現後, 以下1) 上同し槏な癌 化，3）現在檢㣙中ではあるが，EBVゲ/ム陰性リンパ 球上上皮性細胞により形成された雑種細胞へ EBV が直 接感染し, 杂保細胞の㤥儿 EBNA 加発現して, 猚程細 胞がそのまま癌化，4）EBNA 陽性化リンハ球と上皮性 細胞の融合に上る雑種組胞形成上 EBNA 陽性执よびそ の維持という過程老通しての癌化である.

次飞，著者は 1)，4）の問題に関速して，EBNA 晹 性栍種細胞逥别を試みた。すなわら，1）の過程と思わ れる EBNA 陽性雑種細胞か5 5 日目より出現し，約 1 力 月捘には EBNA 陽性雑種勫胞はコロニーを形成した。 そこで，その途中，細胞融合㣪 EBV 感染して，約 2 週目よりクローニングを試み，EBNA 陽性雑種細胞の 分赝を計ったが成功しなかった，しかし，Glaser ${ }^{49) 503}$ ら 注 Detroit 98 細胞の HGPRT 欠据株之 P3HR-1 細胞 との細胞融合を行ない, HAT 選択培地にて,この雑種 細胞（D98/HR-1）の選别成功し，しか子 EBNA 陽 性を示したと報告している。すなわち，野生型の細胞恃， 核酸合成回路として de novo 合成回路と salvage 回路 をすち，細胞が核酸合成增殖するにはどちらか一方の回 路でも可能である.ところが aminopterin は de novo 回 路を阻害するため, HGPRT 欠損株は salvage 回路（こ の回路に HGPRT が必要とする)，を利用できず aminopterin 存在下では核酸合成が不能となる。とこるが， HGPRT 欠損株も他の野生型細胞之の細胞融合により HGPRT 支配ゲノム衣爑得し，融合雑種細胞となれば， この醉素を利用できるので，HAT 培地で核酸合成，增 殖が可能となる。さらK，野生型細胞がリンパ球である ならば, 細胞融合後, 頝回の液交換により浮遊状の野生 型であるリンパ球は除去可能となる。その結果, HAT

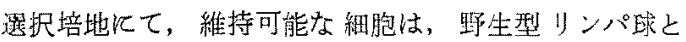
HGPRT 欠指株との雑種紐胞のみとなり，雑種細胞の 選别增殖加可能となる。加加機序により，EBNA 晹 性雑種細胞方造别是れた。

そこで，蓄者香，この原理を利用して，上記 4）の過 程之関連して 2-27-Ad 細胞の HGPRT 欠損株をつく り，EBNA 陽性リンパ芽球細胞である $A_{2} L$ 細胞との 細胞融合後，HAT:培地にての嶕種細胞の選別を行なっ

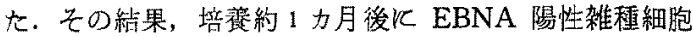
の選別ができた，かかる細胞は，上咽頭癌発生機序解明 のため，さらにヌードマウスるる異種移植実験，そして

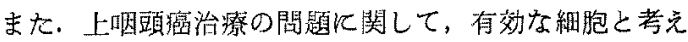
られ，現在ひきつつき検討中である．ただ，生体内に括 ける上咽頭颗発生には，かかる上述のごとき機作で上咽 頭上皮性細胞が癌化し得たとしても，その癌化細胞の増

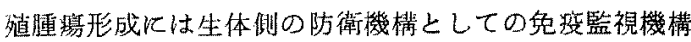
の関与の检討も必要となる. その点の問題はさらに別の in vivo のレベルから追求しなりればならず，本実験に 特ける in vitro のレベルとは当然翼ってくるであるう と思われる。

\section{V 結唔}

人癌ウィルスの1つの候補である EBVと上咽頭癌の 関係汇は，兒在多くの報皆が知られている。しかし，リ

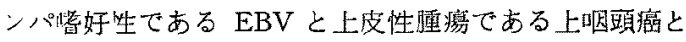
の関連性は一見奇異飞思われる.そこて，著者は in vitro での EBVKよる上咽頭癌発生機解明の奏騃的研究を 行い, 次の結藇を得太。

1）上咽頭癌組織（上咽頭生检ならびに頝部輁移りンパ 節）12例による染抹標本とその初代培葬細胞の EBNA の検索を行った，その結果 a) 渠抹標本 8 例中 4 例（50 \%) は EBNA が晹性であった，b）初代培䧺 12例中9

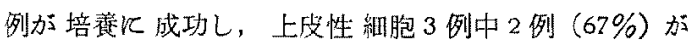
EBNA 陽性索示した。，c）線維芽様細胞培盖中，1例火 浮遊細胞加出現し，樹立化任成功した。

かかる細胞は， EBNA 陽性（90\%以上）で，リンパ

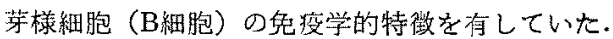

2）各種ヒト由来培筷細胞への EBV 直接感染実験を行

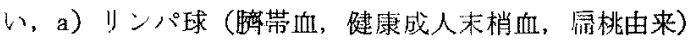
はトランスフォーメーションすることができた（CBL$\left.\mathrm{E}^{-1}, 5, \mathrm{APL}-\mathrm{E}-1 \sim 5, \mathrm{TON}-\mathrm{E}-1,2\right)$ これらりンパ芽 球㥞細胞は EBNA（90\%以上）血性で，B細胞の特徽を 有していた，b）単層培堭細胞への直接感染は，多くの もので成功しなかった。ただ上咽頭（アデノイド）由染 線維芽様細胞への直接感染にて, 浮遊細胞の出現を認め $\left(\mathrm{A}_{1} \mathrm{~L}, \mathrm{~A}_{2} \mathrm{~L}, \mathrm{~A}_{3} \mathrm{~L}\right.$ 細胞)，これらの細胞は樹立化された が，EBNA (90\%以上) 陽性で，リンパ牙球細胞（B緗 胞）の特徽を有していた。

3） a）EBNA 陰性ヒトリンパ球と 2-27-Ad 細胞（上 咽頭由来”上皮性細胞) との UV 不活化 HVJ による細 胞瀜合後の EBV 感染にて, リンパ球の核ならびに2- 
27-Ad 細胞の核雨者飞 EBNA が発現した。しかも， かかる細胞の IudR $(70 \% \mathrm{~g} / \mathrm{m} l)$ の添加刺激培虔にて, 融合細胞に ENA，EA の発䍐を款明できた。 b) 細胞 融合前 EBNA 陰性であったアデノイド由来リンパ球の 万ち，1 例に 2-27-Ad 細胞との細胞融合にて，融合細 胞内リンパ球ならびに 2-27-Ad 細胞の核に EBNA の 発現を婄めた。

4) $\mathrm{A}_{2} \mathrm{~L}$ 細胞と 2-27-Ad 細胞 HGPRT 久損株との UV 不活化 HVJ Kよる組胞融合後, HAT 堮地で選别 培養し，EBNA 陽性の雑種細胞（单層培細胞）の選 別成功した. かかる細胞は，現在に至るも（約 6 力月 閏) EBNA 陽性を維持し績けている.

以上の成績より，上咽頭上皮性細胞への感染機序とし $\tau$,

1) EBVゲノム除性リンパ球と上咽頭性細胞が自然融合

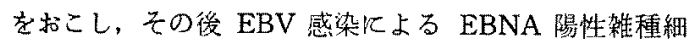
胞の形成.

2) EBV ゲ/ んを㷵めるが EBNA を発現しないリンパ 球と上咽頭上皮細胞融合による外因性の刺激をうけ， EBNA の発現, さらには EBNA 隄性雑種細胞の形成. 3）EBNA 陽性リンパ球と上咀頭上皮性細胞との細胞融 合後の EBNA 隄性雑種細胞化形成.

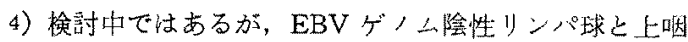
頭上皮細胞の細胞融合後の雑程細胞形成後の EBV 感染 成立による EBNA の発琴。

以上の 4 点の機作驾考光られた。加加る EBNA 隄性 雑程細胞形成が上咽頭発生入密接な関連性を有するもの と推論された.

\section{参考文献}

1) Old $L J$, Boyse $E A$, Oettgen $H F$, de Harien $E$, Geering $G$, Williamson $B$ and Clifford $P$

Precipitating antibody in human serum to an antigen present in cultured Burkitt's lymphoma cells. Proc Nat Acad Sci USA 56; 1699-1703, 1966.

2) Ito $Y$, Takahashi $T$, Kawamura $A J r$ and $T u$ $S M$ : High anti-EB virus titer in sera of patients with nasopharyngeal carcinoma.. A small scaled seroepidemiological study. Gann 60. 335$340,1969$.

3) Kawamura $A J r$, Takada $M$, Gotoh A, Hamaiima $T$, Sanpe $T$, Murata $M$, Ito $Y$, Takahashi
$T$, Yoshida $T$, Hirayama $T, T u S$, Liu $C$, Yang $C$ and Wang $C$ : Seroepidemiological studies on nasopharyngeal carcinoma by luorescent antibody techniques with cultured Burkitt lymphoma cell. Gann 61; 55-71, 1970.

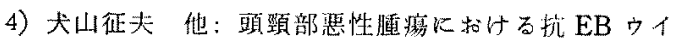
ルス抗体価。日耳骨 78：729-737，1975。

5) Ida S, Hinuma $Y$, Chu J, Lai J, Yang $C$, Lynn $T, H s u M, T u S$ and Kawamura $A J r$ : Further studies on antibodies to early antigen induced by Epstein-Barr virus in nasopharyngeal carcinoma patients. Gann 64; 545-553, 1973.

6) Zur Hausen H, Shulte-Holthausen H, Klein G, Henle $W$, Clifford $P$ and Samtessen $L$ : EBV DNA in biopsies of Burkitt tumors and anaplastic carcinomas of the nasopharynx. Nature $228 ; 1056-1058,1970$.

7) Nonoyama $M$, Huang $C H$, Pagano $J S$, Klein $G$ and Singh $S$ : DNA of Epstein-Barr virus in tissue of Burkitt's lymphoma and nasopharyngeal carcinoma. Proc Nat Acad Sci USA 70; 3265 $-3268,1973$.

8) Huang $D P$, Ho J H C, Henle $W$ and Henle $G$ : Demonstration of Epstein-Barr virus-associated nuclear antigen in nasopharyngeal carcinoma cells from fresh biopsies. Int J Cancer 14;580 $-588,1974$.

9) Glaser $R$, de The $G$, Lenoir $G$ and Ho $J H C$ : Superinfection of epithelial nasopharyngeal carcinoma cells with Epstein-Barr virus. Proc Nat Acad Sci USA 73; 960-963, 1976.

10) Miller $G$ and Lipman $M$ : Release of infectious Epstein-Barr virus by transformed marmoset leukocytes. Proc Nat Acad Sci USA 70; 190$194,1973$.

11) Robinson $J E$, Andiman $W A$, Henderson $E$ and Miller $G$ : Host-determined differences in expression of surface marker characteristics on human and simian lymphoblastoid cell lines transformed by Epstein-Barr virus. Proc Nat Acad Sci USA 74; 749-753, 1977.

12) Shope ' $T$, Dechairo $D$ and Miller $G$ : Malignant lymphoma in cotten-top marmosets following 
inoculation of Epstein-Barr virus. Proc Nat Acad Sci USA 10;2487-2491, 1973.

13）山本畯太郎 他：EB ウィルスダ/ムのリンパ球紲 胞から上皮細胞入心移行。日本稳学会総会記求。 $33 ; 121,1974$.

14) Yamamoto $K$, Matsuo $T$ and Osato $T$. Appearance of Epstein-Barr virus-determined nuclear antigen in human epithelial cells following fusion with lymphoid cells. Interviology, 6; 115-121, $1975 / 76$

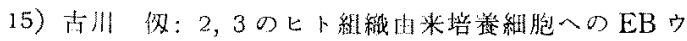
イルスダ/ムの移行。手全医学誌 84；190-210， 1975.

16) Reedman $B M$ and Klein $G$ : Cellur localization of an Epstein-Barr virus (EBV) - associated complement - fixing antigen in producer and non-producer lymphoblastoid cell lines. Int $J$ Cancer 11; 499-520, 1973.

17) Suzuki $M$ and Hinuma $Y$ : Evaluation of EpsteinBarr virus-associated nuclear antigen with various human cell lines. Int J Cancer 14; 753-761, 1974.

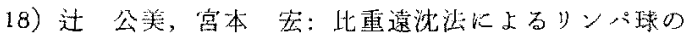

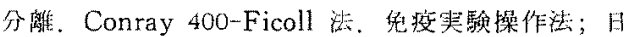
本免痿学会編 265-269，1971。

19) Moss $D J$ I and Pope J H: Assaying of the infectivity of Epstein-Barr virus by transformation of human leukocytes in vitro. J Gen Viol 17 : 233-236, 1972.

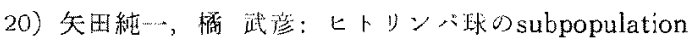

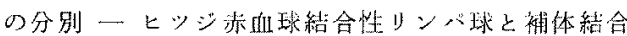
性リンバ球の証明法。免疫寒駼操作法 日本免疼学 会较 $473-475,1972$.

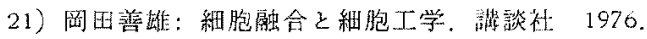

22) Okada $Y$ and Maruyama $Y$ : Requirment of carcium ions for cell fusion reaction of animal cells by HVJ. Exp Cell Res 44; 527-551, 1966.

23) Sugawara $K$ and Osato $T$. Immunoffuorescent antigen associated with Epstein-Barr virus induced by 5-iododeoxy-uridine. Nature New Biology 246; 72-73, 1973.

24) Matsuo $T$, Yamamoto $K$ and Osato $T$ : Differential induction of Epstein-Barr virus-related antigen in human lymphoblastoid cells by virusmediated cell-to-contact. Int J Cancer 17; 423$428,1976$.

25) Henle $W$, Henle $G$, Zajac B, Pearson $G$, Waubke $R$ and Scriba $M$ : Differential reactivity of human serums with early antigens induced by Epstein-Barr virus. Science 169; 188-190, 1970.

26) Hinuma $Y$, Sairenji $T$ and Ohta-Hatano $R$ : Detection of antibody to a new antigen induced by Epstein-Barr virus in serums from patients with malignant lymphoid disease. Japan Acad Sci 46;989-992, 1970.

27) Szybalski $W$, Szybalska $E H$ and Ragni $G$ : Genetic studies with human cell lines. Nat Cancer Inst Monogr 7; 75-89, 1962

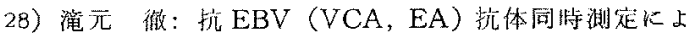

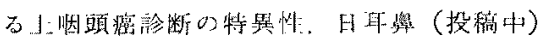

29) Southan C $M$ : Growth of human adenocarcinoma cells in tissue culture. Cancer 7; 394-409, 1954.

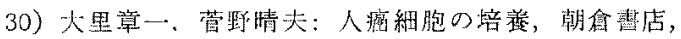

31) Suzuki $M$ and Hinuma $Y$ : Relationship between Epstein-Barr virus-associated nucler antigen and cell viability in human cell lines. Gann 66; 103 $-105,1975$.

32)大黒外篦蚛 (私售)

33) Hinuma $Y$ and Grace $J r J T \cdot$ Cloning of Burkitt lymphoma cells culture in vitro. Cancer $22 ; 1089-1095,1968$.

34) Miller $G$, Robinson $J$, Heston $L$ and Lipman $M$ : Differences between laboratory strains of Epstein-Barr virus based on immortarization, abortive infection and interference. Proc Nat Acad Sci USA 71; 4006-4010, 1974.

35) Menezes $J$, Leibold $W$ and Klein G: Biological differences between Epstein-Barr virus (EBV) strains with regard to lynphocyte transforming ability. Exp Cell Res 92; 478-484, 1975.

36) Osato $T$ and Ito $Y^{\prime}$ : Morphological alteration of human embryo cells in vitro by treatment with human leukemic culture fluid. Proc Nat Acad Sci USA 57; 1076-1079, 1967

37) Probert $M$ and Epstein $M A$ : Morphological transformation of human fibroblasts by Epstein- 
Barr virus : Preliminary observations. Science $175 ; 202-203,1972$.

38) Takada $M$ Linn Y-C, Shiratori $O$, Sugano $H$, Yang C-S, Hsu M-M, Lynn T-C, Tu S-M, Chen H-C, Hamajima $K$, Murata $M$, Gotoh $A$, Kawamura A Jr, Yoshida T O, Osato $T$ and Ito $Y$ : Cultivation in vitro of cells derived from nasopharyngeal carcinoma. Gann Monogr 10; 149-161, 1971.

39) Takada $M$, Kawamura $A$ Jr and Sugano $H$ : transformation of the cultured cell sheets of nasopharyngeal carcinoma by extracts of P3HR 1 and NPC 204 cells carrying herpes-type virus. Gann Monogr 10; 163-171, 1971.

40）梢木絢子他：上卜結合被より分離した線維芽細胞 に和ける $\mathrm{C}_{3}$ リでターについて 医学のあゆみ 101: $544-545,1976$.

41) Klein $G$, Yefenof $E$, Falk $K$ and Westman $A$ : Relationship between Epstein-Barr virus (EBV) - production and the loss of the EBV receptor /complement receptor complex in a series of sublines derived from the same original Burkitt's lymphoma. Int J Cancer 21; 552-560, 1978.

42) Yefenof $E$ and Klein $G$ : Membrane receptor stripping confirms the association between EBV receptors and complement receptors on the surface of human B lymphoma lines. Int $\mathrm{J}$ Cancer $20 ; 347-352,1977$.

43) Kawamura $A J r$, Chen H-C, Murata $M$, Hamajima K, Suzuki $K$, Sudo K, Takada $M$, Saito $Y$ and Sawaki $S$ : Heterotransplatation of cultured cells ane biopsies derived from nasopharyngeal carcinoma in thymus-less (nude) miceJapan J Exp Med 46; 351-362, 1976.

44) Miyoshi $I$, Kubonishi I, Uchida H, Hiraki S, Matsuda $Y$, Tanaka $T$, Masuji $H$, Hiraki $K$ : Production of lymphoid tumors in hamsters by direct implantation of normal human peripheral and umblical cord leukocytes. Int J Cancer 18; $67-75,1976$.
45) Trumpe P A, Epstein $M A$ and Giovanella $B C$ Activation in vitro by BudR of a productive EB virus infection in the epithelial cells of naso: pharyngeal carcinoma. Int J Cancer 17; 578-587, 1976.

46) Gazzolo $L$, de The $G$, Vuillaume $M$ and $H o H$ $C$ : Nasopharyngeal carcinoma. II. Ultrastructure of normal mucosa, tumor biopsies, and subsequent epithelial growth in vitro. J Nat Cancer Inst $48 ; 73-86,1972$.

47) Vuillaume $M$ and de-The $G$ : Nasopharyngeal carcinoma. III. Ultrastructure of different growth leading to lymphoblastiod transformation. J Nat Cancer Inst 51; 67-80, 1973

47）大里外誉郎 他：I 人がんとへルさスウイルス一 $\mathrm{EB}$ ウィルメーEBウィルスに上る in vitro

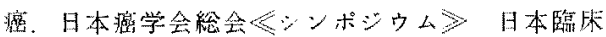
34: 26-35, 1975.

49) Glaser $R$ and Rapp F: Rescue of Epstein-Barr virus from somatic cell hybrids of Burkitt lymphoblastoid cells. J Viol 10; 288-296, 1972.

50) Glaser $R$, Ablashi $D V$, Nonoyama $M$, Henle $W$ and Easton $J$ : Enhanced oncogenic behavior of human and mouse cells after cellur hybridization with Burkitt tumor cells. Proc Nat Acad Sci USA 74; 2574-2578, 1977.

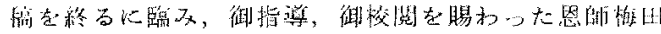

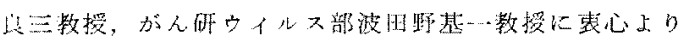

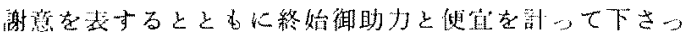

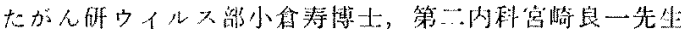
に感識致します。妾た細胞の分与をいたたいた東大医利

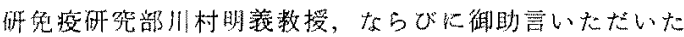

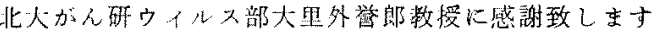

本論文の要旨は，第79间日耳算総会，第15回日本細菌

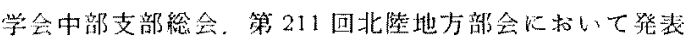
した。

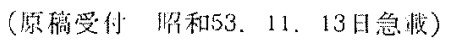

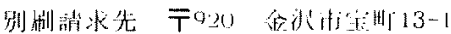

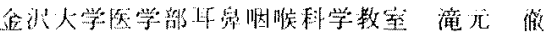

